\title{
EL PROCESO CONTRA ABŪ 'UMAR AL-TALAMANKT A TRAVÉS DE SỤ VIDA Y DE SU OBRA
}

Por

\author{
MARIBEL FIERRO
}

\section{Los datos biográficos (1).}

1.1. Ahmad b. Muhammad b. 'Abd Allāh b. Abī 'T̄sà Lubb b. Yahyà b. Muḥammåd (b. 'Umar) b. Qarlamān (2), Abū 'Umar, al-Ma'āfirī al-

(1) Estudios previos sobre al-Talamanki son los realizados por Pons Boigues, F., Ensayo bio-bibliográfico sobre los historiadores y geógrafos arábigo-españoles (Madrid 1898), n 85; Kahhāla, U.R., Mu'ýam al-mu'allifin (15 vols., Damasco 1957-61), II, 123-4; Asín Palacios, M., Abenházam de Córdoba y su Historia critica de las ideas religiosas, vol. I (Madrid 1927), p. 100, nota 1; Makki, M.A., Ensayo sobre las aportaciones orientales en la España musulmana (Madrid 1968), p. 147; Cabanelas, D., Ibn Sida de Murcia. El mayor lexicógrafo de al-Andalus (2“ ed., Murcia 1986), pp. 38-9 y 42-5; Urvoy, D., El mundo de los ulemas andaluces del siglo V/XI al VII/XIII (Madrid 1983), pp. 73, 108-115, 126-7, 14751; Wasserstein, D., The rise and fall of the Party-kings (Princeton 1985), pp. 179-80; Fierro, $M^{3}$ I., La heterodoxia en al-Andalus durante el periodo omeya (Madrid 1987), pp. 88, nota 40; 139, nota 52; 166, 168; Ibn Hamādi, 'U., "Qadiyyat Abī "Umar al-Talamankī al-Andalusī", Dirāsāt andalusiyya 3 (1410/1989), pp. 5-21 y "Karāmāt al-awliyā' al-niqāš al-hādd allađ̣ atāanat-hu bi-I-Qayrawān wa-Qurtuba fī awājir al-qarn 4H./10M.", Dirāsāt andalusiyya 4 (1990), pp. 354-379. En el estudio de Bosch Vila, J., "El Oriente árabe en el desarrollo de la cultura de la Marca Superior" (Madrid 1954), no he encontrado ninguna referencia a al-Talamanki.

(2) Las fuentes que recogen la biografia de al-Talamankī son (para las siglas utilizadas, $v$. la relación de fuentes al final de este artículo): $H, n^{\circ} 187 ; D, n^{\circ} 347$; IB, n०90; TM, VIII, 32-3; DM, I, 178-80; SD, XVII, 566-9, n³74; TH, III, $1098-$ 1100 ; al-Dahabi, al-Ibar fi jabar man gabar (Kuwait 1961), III, 168; WS, VIII, $32-$ 3; NT, III, 379-80; Ibn al-Ŷ̀azar̄, Gāyat al-nihāya fi tabaqāt al-qurrā' (ed. G. Bergstraesser y O. Pretzl, 3 vols, en 2, El Cairo 1932-3), I, 120, $n^{\circ} 554$; al'Umarī, Masālik al-abșār fi mamālik al-amșār (ed. F. Sezgin, Frankfurt 1988). 
Ṭalamankī al-Muqri', nació en el año 340/951 y murió en el mes de dū Iḥiŷŷa del año 428/1036 o 429/1037 (3), a la edad de 86 o 85 años (89 años lunares).

La nisba "al-Ma'āfirī" es árabe y corresponde a una tribu qahțāní lo de los árabes del Sur); es mencionada por Ibn Baškuwāl y el cadí 'iyãd. El ma‘āfirí más famoso de al-Andalus es Almanzor; aparte de su familia, los Banū $A b \bar{i}$ 'Āmir, Ibn Hazm cita la presencia de familias ma'āfiríes en el levante de al-Andalus (4). De la ausencia de cualquier mención a la genealogía de Abū 'Umar al-Talamankī en la Ŷamhara (5) podría deducirse que en opinión de lbn Hazm (que fue discípulo suyo) no era árabe. De hecho, el nombre Qarlamān del antepasado en el que termina su nasab parecería indicar un origen muladí (6); sin embargo, hay que señalar que un hijo de Badr, el famoso mawlà de 'Abd al-Rahmañn I procedente de Oriente, se llamaba Oarlamān (7). Me inclino a penssar que la familia de Abū 'Umar efectivamente no era árabe, pero no disponemos de datos para precisar su origen étnico. Aventuro la posibilidad de que la nisba "al-

I, 134-5; Vizcaíno, J.M., "Andalusíes en Mīzān y Mu'în de al-Dahabī y Lisān al-mizān de Ibn Haŷar", EOBA IV (ed. L. Molina, Granada 1990, pp. 71-94), nº 41 (Mu'īn); al-Maqrīzī, al-Muqaffà: v. Fierro, $M^{*}$ I. y $M^{*} M$. Lucini, "Biografías de andalusíes en al-Muqaffā de al-Maqrīī (m. 845/1442)", EOBA III led. $M^{*} \mathrm{~L}$. Ávila, Granada 1990, pp.215-56), no 16; al-SuyūțT, Tabaqāt al-mufassirīn (Leiden 1839), $n^{\circ} 8$ (v. Guardiola, $M^{\circ} D$., "Biografías de andalusíes en dos obras de al-Suyūtī" (EOBA IV, Granada 1990, pp. 215-324), n 185); Majlūf, M., Šaýarat al-ñür ( 2 vols. en 1 . El Cairo 1349-50/1930-1), $n^{\circ} 306$; v. también Ávila, $M^{*}$ L., La sociedad hispanomusulmana al final del califato (Madrid 1985) , $n^{\circ} 267$. Las fuentes principales son Abū 'Amr al-Dānī e lbn Baškuwāl. Para sus obras y transmisiones, v. IJ, I, 259, 288, 430-1, 443-4.

M. Asín Palacios señala en su estudio Abenmasarra y su escuela (Madrid 1914), p. 90, nota 2, la existencia de una biografía de al-Talamanki incluida en el manuscrito del Museo Jalduni de Túnez descrito por F. Codera ("Un manuscrito árabe-español en Túnez", Boletín de la Real Academia de la Historia LVIII (1911), pp. 285-96): este manuscrito, cuyo autor se desconoce, parece perdido: $v$. al respecto Fierro, $M^{*}$ I., "Una fuente perdida sobre los ulemas de al-Andalus: el manuscrito del Museo Jalduni de Túnez", Al-Qanțara, XII (1991), pp. 273-6.

(3) La fecha de 429/1037 es transmisión de su discípulo Hātim al-Tarābulusĩ y la de nacimiento está tomada de su contemporáneo, el almocrí Abū 'Amr al-Dānī (m. 444/1052) apud IB.

(4) V. Terés, E., "Linajes árabes en al-Andalus segün la Ŷamhara de lbn Hazm", AlAndalus XXII (1957), pp. $5-111$ y $337-376, n^{\circ} 61$ (pp. 349-50). No sé en qué se basa Urvoy para afirmar que los ma'áfiríes son qaysies (una de las ramas de los árabes del Nortel.

(5) Ibn Hazm lo menciona como informante suyo en una ocasión: v. la edición de Beirut $1403 / 1983$, p. 167.

(6) Ibn Hamādī, "Qadiya", p. 16 así lo considera.

(7) V. Fierro, $M^{*}$ I., "Familias en el Ta'rīj iftitāh al-Andalus" de lbn al-Qūtivya", EOBA I, pp. 41-70, p. 54. V. otro caso de presencia del nombre de Qarlamān en un nasab aparentemente árabe en Ávila, Sociedad, $n^{\circ} \mathrm{s} 7$ ('Abbās b. Yahyà b. Qarlamān al-Lajmī, m. 426/1034) y cf. n³20 (Aḥmad b. Qarlamān al-Mu'addib, m. 377/987). 
Ma‘āfirī" proceda de una relación de clientela con Almanzor, aunque no puedo ofrecer ninguna evidencia al respecto.

La nisba "al-Talamankī" refleja su lugar de origen, Talamanca, donde nació (8). Señala Cabanelas que en Talamanca "poblado de la actual provincia de Madrid, partido judicial de Colmenar Viejo, cerca del río Jarama, existió, durante su gran florecimiento científico en los siglos $X Y$ $\mathrm{XI}$, una escuela de derecho, citada al lado de las de Córdoba y Toledo, como una de las más acreditadas" (9). Al-Talamankī se estableció en Córdoba y según al-Dahabī, el comienzo de sus estudios (samā') fue en el año 362/972, a la edad de 22 años. Llegó pues Abū 'Umar a Córdoba hacia finales del califato de al-Hakam II (350/961-366/976).

1.2. En Córdoba estudió con numerosos ulemas durante una estancia que parece hay que fechar entre los años $362 / 972$ y 375/985; parece también que compaginó sus estudios con el trabajo como copista (10). Vivió pues al-Talamankī en Córdoba entre finales del califato de al-Hakam II y a comienzos del gobierno de Almanzor (m. 392/1002). Fue ésta una época de intensa actividad intelectual no sólo dentro de las disciplinas tradicionales (11). La difusión de las ciencias no islámicas ("ulūm alawä'il) como la filosofía, medicina, astronomía, lógica, etc. acabó por despertar la enemiga de algunos grupos de alfaquíes, produciéndose la censura de la rica biblioteca de al-Hakam II y la persecución de los ulemas que se habían dedicado a ellas, aunque estos intentos represivos no lograron poner fin al interés y cultivo por dichas ciencias. El mu'tazilismo también pervive y se empiezan a conocer en al-Andalus las doctrinas teológicas de al-As‘ari (m.324/935) y sus discípulos (12). Entre los mālikíes se producen algunos intentos por incorporar la doctrina šāfi‘i de los ușül al-figh, especialmente bajo la influencia de la labor desarrollada por

(8) V. al respecto al-Himyarī, Rawd al-mi'tār, ed. y trad. parcial de Lévi-Provençal, E., La Péninsule ibérique au Moyen Age (Leiden 1938), p. 128/155 y Yãqūt, Mu'ýam al-buldān (5 vols., Beirut s.d.), IV, 39. Talamanca fue fundada por el emir Muhammad (238/852-273/886).

(9) Ibn Sida de Murcia, p. 38, nota 4, donde remite a Asín Palacios, Abenházam de Córdoba, vol. I, p. 100, nota 1. Sobre la escuela jurídica de Talamanca, v. también Makki, M.A., Ensayo sobre las aportaciones orientales en la España musulmana (Madrid 1968), p. 108.

(10) Para la última fecha $v$ esta deducción, v. IA (A), 2199, biografía de 'Abd alMaŷĩd al-fatà, uno de los fatà de al-Hakam II, de Córdoba. Estudió con Ibn 'Awn Allāh el Sahĭh de al-Bujārī en la riwāya de lbon al-Sakan; al-Talamankī le escribió una copia de esa obra durante su estancia en Córdoba li-samā' al-'ilm, hacia el final de esa estancia en el año 374/984. Teniendo en cuenta que el maestro mencionado con el $n^{\circ} 3$ enseñó en Córdoba entre los años 375/985-376/986, hay que deducir que al-Talamankĩ debió abandonar Córdoba entre esos años.

(11) Para la exposición que sigue, v. Fierro, Heterodoxia, pp.149-170.

(12) V. Fórneas, J. M", "De la transmisión de algunas obras de tendencia aš'arí en alAndalus", Awräq | (1978), pp. 4-11. 
Ibn Abī Zayd al-Qayrawānī (m. 386/996) (13). Se produce paralelamente un aumento de los estudios del hadit. La progresiva complejidad de las creencias dio lugar a polémicas en torno a cuestiones religiosas como la nubuwwa de las mujeres y los milagros de los santos, polémica esta última en la que como veremos participó al-Talamankī.

Las fuentes mencionan a los siguientes maestros (14):

1) 'Abbās b. Așbag b. 'Abd al-'Azīz al-Hamdānī al-Hiŷārī, Abū Bakr (m. 386/996), cordobés, maestro también de lbn al-Farađợ, quien habla elogiosamente de él, y de Abū 'Umar b. 'Abd al-Barr. Fue autor de una Fahrasa (15).

2) 'Abd Allāh b. Muhammad b. 'Ā̄ b. Şarīa al-Bāŷī, Abū Muhammad (m. 378/988), sevillano, se formó con maestros de Sevilla, Córdoba y Elvira. Experto en hadit y fiqh mālikí, se le elogió como tal. Enseñó en Córdoba entre los añ்os $368 / 978$ y $370 / 980$ (16).

3) 'Abd Allāh b. Muhammad b. al-Qāsim b. Hazm al-Qala'ī al-Tagrī, Abū Muhammad (m. 383/9̇93). Tras estudiar en Túdela, Madinat al-Faraŷ́ y en Toledo, viajó a Oriente en el año 350/961, estudiando con destacados ulemas de Iraq obras de hadīt como al-Musnad y al-'/lal de Ibn Hanbal, así como los Ahkām al-Qưr'ān de lbrāhīm b. Sa'îd al-Bașrī al-Mālikī. De regreso a al-Ándalus destacó por sus prácticas piadosas y por su dedicación al yihād, siendo descrito como hombre valiente y esforzado jinete. AlHakam Il lo nombró cadí de su ciudad natal, Calatayud, pero él pidió ser dispensado de tal cargo. Era alfaquí muy devoto que se abstenía de todo lo ilícito; por todas estas cualidades se le comparó con Sufyān al-Tawrī. Censuró a ciertos hombres del sultán que había en su región natal algo que habían hecho (wa-ankara 'alà ba'd ashāb al-sultān fi nāhiyati-hi say'an): fue calumniado por ello y se le obligó a trasladarse en Córdoba, donde permaneció desde el año 375/985 al 376/986 y donde enseñó entre otras obras el Kitāb ma'ānīl-Qur'ān de al-Zaŷŷāŷ (17).

4) Aḥmad b. 'Awnn Allāh, Abū Ŷa'far (m. 378/988). Parece que fue su maestro más importante, con el que por otro lado estableció relaciones de parentesco, ya que casó con una sobrina suya (hija de un hermano). Ibn 'Awn Allāh estudió en Córdoba con tradicionistas de la talla de Qāsim b.

(13) V. Fónneas, J. M*, "Recepción y difusión en al-Andalus de algunas obras de Ibn Abī Zayd al-Qayrawānī", Homenaje al Prof D. Cabanelas Rodríguez (2 vols., Granada 1987), I, 315-44.

(14) V. Marín, M., "Los ulemas de ai-Andalus y sus maestros orientales (93-350/711961)" EOBA /I, pp. 257-306 para los maestros de los maestros de al-Talamanki.

(15) V.IF, n० 883; H, n० 728; Pons, Ensayo, n 55; Ávila, Sociedad, n 4; Fórneas, J. $\mathrm{M}^{\circ}$, Elencos biobibliográficos arábigoandaluces. Estudio especial de la "Fahrasa" de Ibn 'Atiyya al-Garnātí 1481-541/1088-1147) (Extracto de Tesis Doctoral, Madrid 1971), p. 14.

(16) V.IF, $n^{\circ} 740 ; \mathrm{H}, \mathrm{n}^{\circ}$ 529; Ávila, Sociedad, $\mathrm{n}^{\circ} 62$. V. sobre esta familia Vizcaíno, J.M., "Los al-Bāŷ̀i al-Lajmī de Sevilla", E.O.B.A. V (ed. M. Marín y J. Zanón, en prensa).

(17) V. IF, $n^{\circ} 751 ; \mathrm{H}, \mathrm{n}^{\circ}$ 536; TM, VII, 24-7; Ávila, Sociedad, $n^{\circ} 74 . \mathrm{V}$. también alRušātī e Ibn al-Jarrāt, Al-Andalus en el "Kitāb iqtibās al-anwār" y en el "ljtișār iqtibà̀s al-anwār" (ed. E. Molina - J. Bosch Vilà, Madrid 1990), pp. 34, 184. 
Așbag e Ibn Dulaym. Durante su riḩla visitó La Meca, Trípoli de Oriente, Damasco y Mișr, estudiando entre otros con el gramático y místico Abū Sa'īd b. al-A'räbī (m. 341/953) que había sido a su vez discípulo de alŶnayd (m. 298/910) (18). Se le describe como hombre enérgico en la defensa de la sunna y en la condena de los innovadores ( $k \bar{n} a$... șāriman fi l-sunna mutasaddidan 'alà ahl al-bida') (19). En la biografía de Muhammad b. Mawhab al-Tuŷībī al-Oabrī, nos informa el cadí 'lyād que Ibn 'Awn Allāh "era el jeque de los tradicionistas, estando al frente de un grupo de sus discípulos" (kāna \ayj al-muhadditīn fi tā'ifa min ashābi$h i)$, entre ellos Abū "Umar al-Talamankī. También nos informa que hubo disputas entre Ibn Mawhab e lbon 'Awn Allāh en lo relativo a la cuestión de las karāmāt al-awliyā' (milagros de los santos): Ibn Mawhab, siguiendo la doctrina de Ibn Abī Zayd al-Qayrawānī, se oponía al exceso al respecto, mientras que Ibn 'Awn Allāh, al-Țalamankī y los otros las declaraban lícitas (20). Otro punto de discusión era la cuestión de la nubuwwa de las mujeres: Ibn Mawhab, junto con al-Așili e Ibn Dakwān, afirmaba que María se contaba entre los profetas mientras que una yamā'a de alfaquíes y tradicionistas lo negaba. La polémica al respecto se hizo especialmente virulenta tras la muerte de Ibn 'Awn Allāh (21).

5) Aḥmad b. Hāmid b. 'Ubaydūn, Abū Ŷa'far o Abū 'Amr, conocido por Ibn Samaŷūn, de la Rușāfa de Córdoba. Estudió en Oriente con lbn Ŷahdam e Ibn Galbūn. Al-Talamankī lo mencionó entre sus maestros (așhāal, calificándolo de sālih̆. Entre sus discipulos se cuenta el cadí Yūnus b. “Abd Allāh Ibn al-Saffằr(22).

6) Ahmad b. 'Tsà b. Sulaymān b. 'Abd al-Wāhid b. Muhannà alAšỹa'T, Abū I-Qāsim, Ibn Abī Hilāl (m. h. 400/1009). Durante su riḥla estudió con Abū Ishāq al-Tammār (23).

7) 'Ali b. Muhammad b. Bišr al-Anțākī al-Muqri', Abū I-Hasan (m. $377 / 987)$. Este experto en las siete lecturas coránicas llegó a al-Andalus en el año 352/963. Tenía además grandes conocimientos de lengua árabe y de cálculo. Por lo que se refiere al derecho, seguía la escuela šāfi'í. AlTalamankī estudió con él las qirā'āt (24).

8) Husayn b. Muhammad b. Nābil, Abū Bakr (m. 372/982). Cordobés, estudió con Aslam b. 'Abd al-'Azīz, Muhammad b. 'Umar b. Lubāba, Ahmad b. Jālid, Ibn Ayman y Qāsim b. Așbag. Durante su rihla tuvo ocasión de estudiar con maestros de La Meca, Alejandría y Mișr. Se

(18) Sobre la influencia de este ulema entre los andalusíes $v$. Marín, M., "Los ulemas de al-Andalus $y$ sus maestros orientales (93-350/711-961)", EOBA /I/ (Granada 1990), pp. 257-306 especialmente p. 261.

(19) V. IF, $n^{\circ} 181 ;$ IB, $n^{\circ} 452 ; D, n^{\circ} 452$ y 1566; Ávila, Sociedad, $n^{\circ} 233$.

(20) V. el estudio de Ibn Hamādi citado en la nota 1, especialmente pp. 364-8.

(21) TM, VII, 190; Fierro, Heterodoxia, pp. 168-9.

(22) V. IB(C), $n^{\circ} 57$.

(23) $\mid B(C), n^{\circ} 30$; Ávila, $n^{\circ}$ 249. No he logrado identificar a ese "Abū Ishāq alTammār" que también fue maestro de ai-Talamanki.

(24) V.IF, $n^{\circ}$ 932; D, $n^{\circ} 1195 ;$ Ávila, Sociedad, $n^{\circ} 371$. 
le recuerda sobre todo como experto en la redacción de contratos y por su conocimiento del ra'y. Destacó también como poeta y filólogo (25).

9) Jalaf. Ibn al-Abbār, que es el único biógrafo que menciona a este personaje, no conoce ni su nasab ni su lugar de origen. Su fuente parece ser el propio al-Talamankī (probablemente a través de su Fahrasa, v. más adelante apartado 1.7.), ya que la única información de que dispone es que llegó a Córdoba, donde enseñó el Kitāb al-sunna de al-Bāzarnī en el maýlis de Ibn 'Awn Allāh, y que al-Ṭalamankī afirmó: "Copié ese libro tomándolo de él y no sé cuál era su nasab (lit.: no sé de quién era hijo)" (26).

10) Jalaf b. 'A గi b. Nāșir al-Balawī al-Sabtī al-Zāhid (m. 400/1009). Es caracterizado como asceta (zāhid mutabattil) giróvago (sā'ih fi l-ard lā ya'wī ila watan). Llegó a al-Andalus desde Ceuta y en Córdoba se estableció en la mezquita de Mut'a donde se dedicaba a prácticas devotas. Allí iban a escucharle las gentes devotas y los ascetas lal-șulahă' wa-lzuhhād). Murió en Elvira al comienzo de la fitna (27).

11) Jalaf b. Muhammad al-Jawlānī al-Mukattib, Abū I-Qāsim (m. 374/984). Cordobés, estudió con Aslam b. 'Abd al-'Az̄̄z, Ibn Ayman, Ibn Abī Zayd, Muhammad b. Miswar, Muḥammad b. Aḥmad al-lšbilı alZāhid, Aḥmad b. al-Šāma, Qāsim b. As̉bag, Aḥmad b̆. Ziyād y otros. Estudió en La Meca con Abū Sa'Tid b. ali-A'rābī y en Qayrawān con Ibn al-Labbād (28).

12) Maslama b. Muhammad b. Maslama b. Muhammad b. Sa`ĩd b. Butrī al-lyādī, Abū Muhammad (m. 391/1000). Fue asceta, piadoso y dedicado al yihãd. Entre sus maestros andalusíes se cuentan Wahb $b$. Masarra, Ibn 'Awn Allāh, 'Abd Allāh b. Muḥammad b. 'Alī al-Bāŷī e lbn Mufarriŷ. Durante su rihla estudió en La Meca con al-Āŷurrī. Enseñó la Mudawwana de Saḥnūn y la Mustajraŷa de al-'Utbī. Entre sus discípulos se cuenta Abū 'Umar b. 'Abd al-Barr (29).

13) Muḥammad b. Aḥmad b. Yahyyà b. Mufarrî̀ al-Qāọi, Abū 'Abd Allāh (m. 380/990), importante transmisor de obras de ascetismo y mística (por ejemplo, de al-Muhāsibī), historia y hadiz (30).

14) Muhammad b̀. Hasan b. 'Abd Allāh al-Zubaydi, Abū Bakr (m. $379 / 989$ ). Se trata del conocido gramático e historiador. Fue uno de los que compusieron una refutación de las doctrinas de Ibn Masarra (31).

15) Muhammad b. al-Husayn b. Muhammad b. Ibrāhīm b. al-Nu'mān al-Muqri', Abū 'Abd Allāh (m். 368/978). De Qayrawān, era un experto en

(25) V. IF, $n^{\circ} 353$; Ávila, Sociedad, $n^{\circ} 480$.

(26) IA(C), n० 790 .

(27) V. IB, $n^{\circ} 400$; Ávila, Sociedad, $n^{\circ} 556$.

(28) V. IF, $n^{\circ} 413$; Ávila, Sociedad, $n^{\circ} 570$.

(29) V. IF, $n^{\circ} 1422 ; H, n^{\circ} 802 ; T M$, VII, 14; Ávila, Sociedad, $n^{\circ} 606$.

(30) V. Ávila, Sociedad, $n^{\circ} 705$; Hermosilla, $M^{a} J$. ., "Una versión inédita del Kitāb bad" al-jalq wa-qisas al-anbiyā' en el ms. LXill de la Junta", Al-Qantara VI (1985), pp. 43-77, donde se recoge una biografía de Ibn Mufarriȳ (pp. 63-67). En Ibn Hazm, Ŷamhara, p. 167 se recoge una transmisión suya a través de al-Talamankī.

(31) V. Pons, Ensayo, $n^{\circ}$ 50; Ávila, Sociedad, $n^{\circ} 726$; Fierro, Heterodoxia, p. 113 , nota 60 y p. 139 , nota 52 . 
el Corán y en sus lecturas, habiéndose formado con maestros egipcios. Llegó a al-Andalus después del 360/970. Al-Talamankĩ estudió con él las qirā'āt (32).

16) Muhammad b. Jalifa b. 'Abd al-Ŷabbār b. Jalifa al-Balawĩ alMu'addib, Abū 'Abd Allāh (m. 392/1001). Cordobés, estudió en La Meca

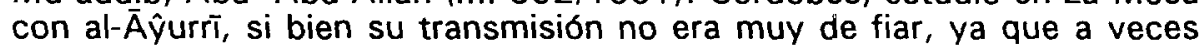
lo confundía con Muhammad b. al-Husayn al-Barŷillānī. De vuelta a alAndalus, se dedicó a la enseñanza dèl Corán (33).

17) Muḥammad b. Yabqà b. Muḥammad b. Zarb, Abū Bakr (m. 381/991). Fue cadí de Córdoba. Había éstudiado con Oāsim b. Aṣbag e Ibn Abī Dulaym. No se dedicó al hadịt sino al ra'y; era experto en masá'il de acuerdo con la doctrina de Mālik y sus discípulos, así como en lengua árabe y cálculo. Fue autor de una refutación contra lbn Masarra y sabemos de su participación en la persecución contra los masarries, en el proceso contra 'Abd al-Malik b. Mundir b. Sa'īd al-Ballūtī (acusado de conspirar contra Hišām II) y tal vez en la quema de los libros de la biblioteca de alHakam II considerados heterodoxos (34).

18) 'Umar b. Muhammad b. 'Umar al-Ŷuhanī al-Mukattib, Abū Hafs (m. 409/1018), de Almería. Transmitió el Kitāb al-arba 'în hadītan de ai-

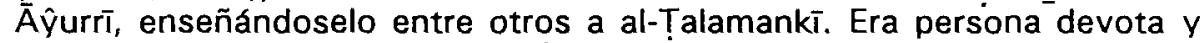
piadosa en la rābița de Almería (35).

19) Yahyà b. 'Abd Allāh al-Layți, Abū 'T̄sà (m. 367/977) (36). Fue cadí en diversas ciudades y destacó en la transmisión de obras jurídicas, entre ellas naturalmente la riwāya de su antepasado Yahyà b. Yahỵà del Muwațtá. Compuso un Kitāb ijtișār sïrat rasūl Allāh. Entre sus discípulos, destaća el cadí Yūnus b. 'Abd'Allāh, contemporáneo de alTalamankī y uno de los numerosos ulemas que murieron en el año $429 / 1038$.

20) Zakariyyā' b. Jālid b. Zakariyyā' b. Simāk al-Dinnī, Abū Yahyà (m. 404/1013). Originario de Guadix, tras estudiar con Q́āsim b. Aṣbag̣ y Sa'īd b. Fahlūn, se estableció en Almería (37).

También se menciona entre los maestros de al-Talamankī a un Ibn Ŷandal y un lbn al-Balkārišĩ a quienes no he podido identificar (38).

(32) V. IF, $n^{\circ} 1400$; Ávila, Sociedad, $n^{\circ} 734$.

(33) V. IF, $n^{\circ} 1385 ;$ Ávila, Sociedad, $n^{\circ} 760$.

(34) V. IF, $n^{\circ} 1361 ; H, n^{\circ} 170 ; T M$, VII, 114-8; Ávila, Sociedad, $n^{\circ} 834$; Fierro, Heterodoxia, pp. 138-9, 140, 156, 162, 166.

(35) $\mathrm{IB}(\mathrm{C}), \mathrm{n}^{\circ}$ 851; Ávila, $\mathrm{n}^{\circ}$ 1037. Al-Talamankī es fuente de IB para la fecha de muerte de este personaje, quien tal vez tuviese contactos con el núcleo masarrí de Pechina, cuyo jefe era Ismā‘îl b. 'Abd Allāh al-Ru'aynī: v. al respecto Fierro, Heterodoxia, pp. 166-8.

(36) V. Ávila, Sociedad, $\mathrm{n}^{\circ} 1072$ y Marín, M., "Una familia de ulemas cordobeses: los Banū Abī 'Īsà", Al-Qantara VI (1985), pp. 291-320, esp. pp. 312-315.

(37) V. IB, $n^{\circ} 430 ; D, n^{\circ} 745 ;$ Ávila, Sociedad, $n^{\circ} 1131$.

(38) El último no puede tratarse del Ibn Buklăriš autor de al-Kitāb al-musta'inni: v. al respecto Labarta, A., "El prólogo de al-Kitāb al-musta'íni (texto árabe $\mathrm{V}$ traducción anotada)", Estudios sobre Historia de la Ciencia Arabe (ed. J. Vernet, 
Con una serie de personajes contemporáneos suyos, al-Talamankī tuvo una relación que era de maestro/compañero. Es el caso de 'Abd alMalik b. Asad b. 'Abd al-Malik al-Lajmī, Abū Marwān. Originario de Sidonia (donde nació en 330/941), se estableció en Córdoba. Discípulo de Ibn 'Awn Allāh, se dedicaba a 'aqd al-surūt en la mezquita al-Zaytūna de Córdoba. Al-Talamankī, quien lo llama sāhỉb, lo mencionó en una de sus obras y transmitió de él un hadīt (39). En el caso de Abū Bakr b.

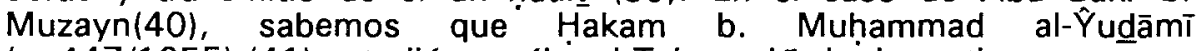
(m.447/1055) (41) estudió con él y al-Talamankī al mismo tiempo.

Los maestros andalusíes de al-Talamanki se dedicaron principalmente al hadit $\left(n^{\circ} \mathrm{s} 3,4,9,12,13,16,19\right)$, siguiendo en orden de importancia el fiqh mālikí ( $n^{\circ}$ s $8,12,17,20$ ). Al-Talamankī aprende las lecturas coránicas con dos maestros orientales establecidos en al-Andalus $\left(n^{\circ} s 7,15\right)$. Uno de sus maestros ( $n^{\circ} 1$ ) es recordado como autor de una Fahrasa, género que empezaba a desarrollarse en al-Andalus (42) y que tan importante desarrollo tendría posteriormente, gracias también a la contribución de alTalamankī. Otros rasgos a destacar de los maestros de nuestro personaje son el ascetismo $\left(n^{\circ} s 3,11,12,13,18\right.$, estos dos últimos próximos a la mística) y su dedicación al yihād ( $\left.n^{\circ} s 3,12,19\right)$ (43), que caracterizarán asimismo a al-Talamankī, de la misma manera que la lucha contra las innovaciones o bida' $\left(n^{\circ} s 4,14,17\right)$, aunque por otro lado al-Talamanki siguió en lo relativo a las karāmāt y la nubuwwa de las mujeres doctrinas que no eran objeto de aceptación unánime dentro de la comunidad musulmana. Dos de sus maestros $\left(n^{\circ} s 14,17\right)$ escribieron refutaciones contra el místico cordobés lbn Masarra, "género" que será cultivado por nuestro personaje.

1.3. Al-Talamankī hizo la rihla a Oriente y la peregrinación en unas fechas que hay que situar entre $375 / 985$ y $381 / 991$ (en este último año

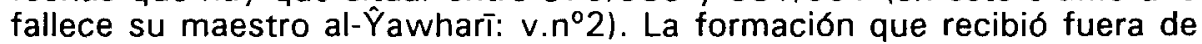
al-Andalus se centró fundamentalmente en el estudio de las lecturas coránicas y en la tradición profética.

Barcelona 1981, pp. 183-317), donde se le sitúa cronológicamente entre la segunda mitad del $s$. XI y la primera del XII (p. 184), por lo que no pudo ser maestro de al-Talamanki. Este Ibn Buklāriš era judio. No hay una interpretación definitiva del término "B.kiār.š" (ibid., p. 184). He tenido también en cuenta la posibilidad de que se tratase de Ibn Baškulārī (v. IB, $n^{\circ} 610$ ), pero este personaje muere en fecha demasiado tardía (año 461/1068) para haber sido maestro de alTalamankī $y$ además no se menciona en su biografía que lo fuera.

(39) $\mathrm{IB}(\mathrm{C}), \mathrm{n}^{\circ} 763$.

(40) IA(C), $n^{\circ} 580$.

(41) V. Ávila, Sociedad, $n^{\circ} 426$.

(42) V. el estudio de Fórneas citado en la nota 15.

(43) V. Urvoy, D., "Sur l'évolution de la notion de gihād dans l'Espagne musulmane". Mélanges de la Casa de Velázquez IX (1973), pp. 335-371. 
Entre los lugares que visitó se cuenta Egipto, ya bajo el dominio de la dinastía fātimí. Allí estudió (44) con:

1) 'Abd̉ al-Mun'im b. 'Ubayd Allāh b. Galbūn, Abū l-Tayyib (m. 389/998) (45), originario de Alepo pero establecido en El Cairo, donde lo encontró al-Talamankī. Gran experto en lecturas coránicas y autor de varias composiciones al respecto (entre ellas el Kitāb al-irs̄ād fi l-sab'), nuestro andalusí estudió con él las qirā'āt.

2) 'Abd al-Rahmmān b. 'Abd Allāh b. Muhammad al-Ŷawharī, Abū lQāsim (m. 381/991) (46). Destacado alfaquí mālikí, compuso un Musnad al-Muwațtá y un Hadīt Mãlik mimmā laysa fi l-Muwatța'. Nuestro andalusí estudió con él en El Cairo.

3) 'Abd al-Wahhāb b. 'T̃sà b. 'Abd al-Rahmān b. Māhān al-Fārisī alBagdāōi, Abū l-'Alā' ' $(m$. 387/997) (47). Al-Talamankī lo encontró en El Cairo. Tradicionista, transmitió el Sahih de Muslim.

4) Ahmad b. Muhammad b. Ismā īi Ibn al-Muhandis al-Bannā', Abū Bakr (m. 385/995) (48), tradicionista con el que al-Talamankī estudió en El Cairo.

4 bis) Ahmad b. 'Abd al-Wahhāb b. al-Husayn b. Yūsuf b. Ya'qūb b. Ismā'ה b. Haimmād b. Zayd al-Bașrī, Abū 'A $A \sqrt{1}$. Establecido en Egipto, compuso una obra de refutación de al-Säfi‘i(49).

5) Muḥammad b. 'A $\bar{T}$ b. Aḥmad, Abū Bakr, conocido por Ibn alUdfuwi (m. 388/998) (50). Experto en lecturas coránicas, compuso un tafsīr al-Qur'ān. Al-Talamankī lo encontró en El Cairo. Según Ibn alŶazarī, al-Talamankī lam yaqra' 'alà al-Udfuwì bal sami'a min-hu l-hurüf, es decir, no llevó a cabo ante su maestro la recitación completa del Corán, sino que aprendió aquellas palabras del Corán que tienen lectura múltiple (51).

6) Muhammad b. Yaḥyà b. 'Ammār al-Dimyāțī, Abū Bakr (m. 384/994) (5'2), șăhib de Ábū Bakr b. al-Mundir (53) (Damieta), de quien escuchó algunos de los libros de Ibn al-Muñdir, alfaquí sāfi‘i, entre ellos el Kitāb al-išräf lobra de ijtilāfl.

(44) Para la identificación de los personajes que vienen a continuación he consultado SD, TH, Ibn al-Ŷyazarī, Mïzän.

(45) V. Ibn al-Ŷazarī, Gāya, n० 1967; IJ, pp. 25-7.

(46) SD, XVI,435-6; DM, I, 470-1; Šadarāt, III, 101; Majlūf, pp. 93-4.

(47) SD, XVI, 535-6; 'lbar, III, 39-40; Šadarāt, Il1, 128-9.

(48) SD, XVI, 462; '/bar, III, 27-8; Šadarāt, III, 113.

(49) TM, VI, 181-2.

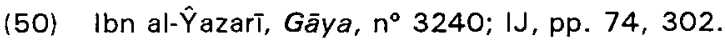

(51) V. al respecto El 2, s.v. harf (H.Fleisch).

(52) SD, XVI, 504.

(53) Se trata del alfaquí šāfi‘í, tradicionista y experto en el Corán Muhammad b. lbrāhīm b. al-Mundir al-Nīsābūrī (m. 318/930): v. GAS, I, 495-6. 
7) TTāhir b. 'Abd al-Mun'im b. 'Ubayd Allāh b. Galbūn, Abū l-Hasan (m. 399/1008) (54). Hijo del $n^{\circ} 1$, fue como él experto en lecturas coránicas y autor de varias obras entre las que destaca al-Tadkira fī /qirā'āt al-țamān.

8) 'Úbayd Allāh b. Muḥammad b. Jalaf b. Sahl b. Abī Gālib al-Mișrī al-Bazzāz, Abū l-Qāsim (m. 387/997) (55), tradicionista. Al-Dahábī recoge la siguiente transmisión de al-Talamankī acerca de este maestro: "Oí decir a lbn Abī Gālib: "Me he esforzado durante diez años en construir esta casa: en ella hay 48 mil piezas de mármol en las que me he gastado diez mil dinares. Kāfūr al-ljšĩīi ha cogido de mí 87 mil dinares, pero vivo del comercio y he ganado por medio de la miel en cuatro días mil dinares". Ibn $A b \bar{~}$ Gālib era por lo tanto un rico mercader, cuyas cuantiosas ganancias no se veían demasiado afectadas por las sumas "prestadas" al gobernador de Egipto, Kāfūr (m. 357/968) (56).

9) 'Umar b. Muhammad b. "Irāk al-Hadramī al-Mișrī, Abū Hafș (m. 388/998) (57), experto en la qirā'a de Warš e imām de la aljama de El Cairo.

\section{En La Meca estudió con}

10) 'A $\bar{\pi}$ b. 'Abd Allāh b. al-Hasan b. Ŷahdam al-Hamadānī, Abū IHasan (m. 414/1023) (58), sayj al-șüfiyya en La Meca. Compuso una obra titulada Bahŷat al-asrär (59) con relatos acerca de los sūfíes que se conserva en la biblioteca Zăhiriyya de Damasco. Los juicios acerca de esta obra no son muy positivos, pues parece que se dejóllevar por su fantasía (se le califica de no ser tiqa y de kaddāb). En ella trataba la mihna de Ibn Hanbal, contando maravillas e historias falsas. También compuso una refútación contra lbn $A b \bar{i}$ Zayd en lo referente a la polémica sobre karāmāt al-awliyāa' (60). Se le considera el que inventó la șalāt alragā'ib (61). identificar).

11) Mụ̣ammad b. Muḥammad b. Ŷibrïl al-'Uŷayfī, Abū l-Ṭāhir (sin

(54) Ibn al-Ŷazarī, Gāya, n 1475.

(55) SD, XVI, 522-3; 'lbar, III, 35; Šadarāt, III, 122; Husn, I, 371.

(56) A.S. Ehrenkreutz (EI 2, s.v.) afirma: "Malgré les difficultés économiques et des dépenses publiques considérables, l'administration de Kāfūr sut éviter la pratique de l'extorsion fiscale...". El caso de lbn Abĩ Gālib ilustra cuál era una de sus fuentes de ingresos.

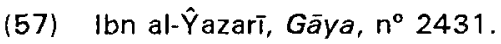

(58) V. su biografía en SD, XVII, 275-6; TH, III, 1057; Mĩāan, III, 142-3; Lisān, IV, 238. En SD se pueden encontrar mencionadas más fuentes.

(59) Es mencionadạ en IJ, p. 295 bajo el título Kitāb al-anwār wa-bahŷat al-asrār fī ajbār al-șālihion con una cadena de transmisión en la que no aparece al-Talamankī.

(60) Es decir, Ibn Ŷahḍam era partidario de los milagros: v. Ibn Ḥamāđi, "Karāmăt", p. 364 .

161) Esta oración se lleva a cabo en los meses de raŷab $y$ ša'bān y se considera una innovación: v. al respecto al-Turțũšī, Kitāb al-ḥawãdị wa-l-bida' (ed. M. Talbi, Túnez 1956), pp. 121-2. 
En Medina con

12) Yaḥyà b. al-Husayn al-Muțallabī, Abū I-Ḥasan (sin identificar).

\section{En Qayrawān con}

13) Ahmad b. Dahmūn/Rahmūn, Abū Ŷa'far (sin identificar).

14) Ib́n Abī Zayd, el famoso alfaquí mālikí autor de la Risāla (62). Para las refutaciones que se escribieron sobre puntos de su doctrina, entre otros por al-Talamankī, v. el apartado 1.7., $n^{\circ} 12$.

Otros maestros a los que no he podido identificar son Ibn Munŷib y Abū Ishāa al-Tammār. Asimismo, se menciona como maestro suyo a alHusayn b. Safwān b. Ishāq b. Ibrāhīm al-Barda'ī, Abū 'Alĭ, tradicionista, discípulo dé $A b u \overline{~ B a k r ~} \dot{b}$. Abī I-Dunyā y transmisor de sus obras. Pero teniendo en cuenta que falleció en Bagdad en el año 340/951 (63) (el mismo año en que nació al-Talamankī), es imposible que fuera su maestro directo.

Los maestros no andalusíes de al-Talamankĩ fueron decisivos en su formación dentro del campo de las lecturas coránicas $\left(n^{\circ} s 1,5,7,9\right)$, así como en el campo del hadít $\left(n^{\circ} s 3,4,8\right)$. Si por un lado tuvo como maestro a un alfaquí mālikí de la talla de lbn Abī Zayd, por otro lado también estudió la doctrina šăfi ‘í $\left(n^{\circ} 6\right)$ con la que ya había entrado en contacto en al-Andalus. El maestro más curioso es Ibn Yahḍam ( $\left.n^{\circ} 10\right)$, cuya influencia debió centrarse sobre todo en el terreno del misticismo.

1.4. Regreso al-Talamankī a al-Andalus habiendo acumulado un gran saber. Esto es algo en lo que insisten los biografos, quienes especifican que su saber residía sobre todo en el Corán y el hadit. Se estableció en Córdoba, donde se dedicó a enseñar a las gentes ordenándoles el bien y prohibiéndoles el mal (wa-aqra'a l-nãs bi-hā muhtasiban (64)). Les enseñó fundamentalmente el hadīt. Fue imām en la mezquita Mut'a. Debió de abandonar Córdoba hacia $403 / 1012$, iniciando un deambular por los reinos de taifas que es característico de la época. Visitó las siguientes ciudades: Almería, Murcia, Zaragoza.

Sabemos que estuvo en Almería, pues allí encontró a Abū I-Qāsim b. Hilāl, de Almería, en el año 403/1012 y le preguntó sobre Zakariyyā' b. Jālid al-Ḍinnī (que había sido maestro de al-Talamankĩ: v. 1.2., $\mathrm{n}^{\circ}$ 18) y otros ulemas de Córdoba y de otras partes de al-Andalus (65). En ese año había tenido lugar la entrada de los beréberes en Córdoba con las

(62) TM, VI, 215-222; SD, XVII, 10-13; Idris, H.R., "Deux juristes kairouanais de l'époque zīrīde: Ibn Abī Zayd et al-Qābisī", AlEO XII (1954), pp. 121-98; El 2, S.V. (H.R.Idris).

(63) SD, XV, 442; 'lbar, II, 253; Šadarāt, II, 356-7.

(64) Otra traducción podría ser "anticipando con ello la recompensa de Dios". Para esta traducción, v. Kister, M.J., "Sanctity joint and divided"(comunicación presentada en el 5th International Colloquium From Jahiliyya to Islam), p. 36.

(65) IA(A), n²540. La fuente es Ḥātim al-Tarābulusī. 
matanzas que trajo consigo (66), por lo que no es de extrañar que alTalamanki inquiriera por los ulemas de Córdoba. Tal vez haya que deducir de este hecho que él había abandonado Córdoba con anterioridad a dicha entrada.

En Murcia coincidió al-Talamankī con Ibn Sìda según una conocida anécdota contada por el propio al-Talamankī y transmitida por su discípulo al-Waqqašĩ: "Entré en Murcia y las gentes me asediaban para que les explicase al-garīb al-musannaf [obra de Abū 'Ubayd al-Harawī]. Les dije: "Buscad a quien os lo lea y yo le seguiré por mi copia". Me trajeron a un hombre ciego, conocido por lbn Sida, quien leyó el libro ante mí del principio al fin. Quedé asombrado de su sabiduría, pues era ciego hijo de ciego". Se trataba, claro está, de Abū I-Ḥasan "A斤̄ b. Aḥmad b. Sida, autor del Muhkam (67).

Su estancia en Zaragoza debió tener lugar entre los años 420/1029 (v. 1.5., $n^{\circ} 7$ ) y $425 / 1034$, fecha en la que se produjo el proceso que veremos en el apartado 2. En Zaragoza estudiaron con él los discípulos $n^{\circ} \mathrm{s}$ 18, 26, 29, 31 y los Banū Fūrtiš. Debió ser en Zaragoza donde se encontró con al-Husayn b. Muhammad b. Mubaššir al-Ansāīi, un discípulo de $A b u ̄$ 'Amr al-D́ānī que fue almocrí en la mezquita aljama de Zaragoza durante cuarenta años y maestro de Abū 'Alī al-Șadafí (68). A Zaragoza deben referirse las fuentes cuando afirman que al-Talamanki marchó a la frontera, donde las gentes pudieron sacar provecho de su saber.

Al final de su vida volvió a Talamanca a hacer vida de ribāt (murābit) (69) y allí murió, como hemos dicho, en el año 428/1036 o 429/1037. Cuenta Ibn Baskuwāl (reproducido en SD) que Abū I-Qāsim Ismā'îl b. 'T̃sà b. Muhammad al-Hiŷārī (70) le contó tomándolo de su padre que alTalamankĩ le comunicó cómo había tenido un sueño en el que alguien le recitaba unos versos en los que se anunciaba su fallecimiento. El sueño se cumplió, pues murió en aquel mismo año.

Algunos de los contemporáneos más destacados de al-Talamankĩ murieron como él en el año 429/1037, hecho éste señalado por los biógrafos de los personajes afectados (71).

1.5. Al-Talamankī tuvo 56 discípulos, siendo uno de los maestros que más influencia ejercieron durante el $\mathrm{s}$. $\mathrm{V} / \mathrm{XI}$ (72). En el estudio

(66) V. al respecto Ávila, Sociedad, p. 39.

(67) La anécdota, recogida en IB, NT y otras obras, fue traducida por Cabanelas, Ibn Sida, p. 39.

(68) V.D. n० 645

(69) Esta información la recoge el cadí 'lyād. Tal y como ya señaló Cabanelas, sobre esta ciudad fronteriza debe verse Torres Balbás, L., "Talamanca $\vee$ la ruta del Jarama", Boletín de la Real Academia de la Historia CXLVI (1960), 235-66.

(70) V. su biografía en $(A \mid C), n^{\circ} 484$, donde se hace referencia a su transmisión del sueño de al-Talamankī premonitorio de su propia muerte.

(71) V. $\mid A(C), n^{\circ} 115$; ha llamado la atención sobre esta coincidencia Ávila, Sociedad, pp. 39-40.

(72) V. el estudio de M. Marín en el t. VIll de la Historia de España fundada por R. Menéndez Pidal y dirigida por J. $M^{*}$ Jover Zamora (en prensa). 
realizado por Urvoy sobre el mundo de los ulemas en al-Andalus durante los ss. V/XI-VII/XIII, al-Talamankī aparece en efecto encabezando la relación de aquellos maestros cuya influencia directa alcanza hasta el año $500 / 1106$.

Entre esos 56 discípulos se cuentan los siguientes:

1) 'Abd Allāh b. Muhammad b. 'Tsà b. Walíd al-Nahwī, Ibn alAslamī, Abū Muhammad, de Madínat al-Faraŷ; vivió también en Toledo. Era experto en gramática y lexicografía, así como en derecho (fiqh) y "verdades de la fe" (i'tiqādāt) (73). Ibn al-Abbār lo presenta como uno de los ashāb de al-Talamankī (74).

2) "Abd Allāh b. Muhammad b. Ismā'ה [b. Muhammad] b. Fūrtiš, Abū Muhammad (m. 495/1101), cadí de Zaragoza. Fue discípulo de Abū I-Walìd al-Bāŷī; al-Talamankī le concedió la iŷāza. Había nacido en $424 / 1032$ (75), por lo que claramente no pudo estudiar directamente con nuestro personaje.

3) 'Abd Allāh b. Muhammad b. Sandūr b. Muntī b. Marwān alTuŷīīi, de Zaragoza (m. a. 500/1106) (76). Su relación de discípulo con al-Talamankĩ debió ser también por iȳāza.

4) 'Abd Allāh b. Sahl b. Yūsuf al-Ansārī al-Muqri', Abū Muhammad (m. 480/1087), de Murcia. Estudió también con Abū 'Amr aí-Dānī y Makkī b. Abī Tālib (77).

5) 'Abd Allāh b. Sa‘īd b. Libāŷ al-Umawì al-Santiŷiyāi al-Tawî, Abū Muhammad (m. 436/1044) (78). Estudió en Córdoba con nuestro personaje. En 391/1000 hizo la rihla, estudiando en La Meca (donde residió varios años) con lbn Ŷahdam y cón Abū Darr al-Harawī, así como con Abū Sa'Tid al-Wā'iz, autor del Kitāb saraf al-Muștafà y con Yahyà b. Naȳāh, autor del Kitāb subul al-jayrāt. Es descrito como zāhid mutabattil munqați ilà rabbi-hi munfarid bi-hi. Hacía ayunos prolongados. Mientras estuvo en La Meca, cuando tenía que hacer sus necesidades salía fuera del territorio considerado haram. Volvió a al-Andalus en el año 430/1038, enseñando el Sahih de Muslim. Abandonó esta ciudad en 433/10.41 con la intención de dirigirse hacia el Garb para hacer vida de ribāt. Regresó luego a

(73) Es difícil precisar el significado exacto de este término técnico en al-Andalus. En los estudios de D.B. Macdonald y L. Gardet en El 1 y El 2 respectivamente (s.v. i'tiqād) se señala que como término técnico designa la firme adhesión a la Palabra de Dios; se utiliza a veces como sinónimo de aqída (credo o profesión de fe). aunque parece estar más especializado para designar las prescripciones coránicas relativas a la fe. En ciertos casos puede designar las convicciones adquiridas racionalmente.

(74) $\left|B, n^{\circ} 574 ;\right| A(C), n^{\circ} 1944$.

(75) IB, $n^{\circ} 631 ; \mathrm{D}, \mathrm{n}^{\circ} 894$.

(76) $\mid A(C), n^{\circ} 1973$.

(77) $1 B, n^{\circ} 625$.

(78) IB, n $n^{\circ} 593$. 
Córdoba, donde murió siendo enterrado junto a la tumba de Așbag b. Mãlik (79).

6) 'Abd al-Bāqī b. Muhammad b. Sa'īd al-Hiŷārī, conocido por lbn Burrāl (m. 502/1108), fue discípulo también de al-Mundir b. al-Mundir b. 'Ali al-Hiyaărī (80). Según noticia recogida por al-'Ābbās b. Ibrāhīm (81), el famoso místico andalusí Abū l-'Abbās b. al-'Arīf (481/1088536/1141) fue discípulo de este lbn Burrāl, estableciendo a continuación la siguiente cadena de transmisón mística: Ibn Burrāl - al-Talamankī - Ibn 'Awn Allāh - al-Hasan b. 'Abd Allāh al-Ŷurȳānī jādim de Ábū Sa'îd b. alA'rābī - Sālim b.'Abd Allāh al-Jurāsānī - al-Fuḍayl b. 'lyāọ - Hišām b. Hassān - al-Hasan al-Bașrī.

7) 'Abd al-Qawī b. Muhammad al-'Abdarī, Abū Muhammad, de Chinchilla (m.d.499/1105) (82).

8) Abū 'Abd Allāh b. al-Șaffār, de Zaragoza. Entiendo que era el qāri' de al-Ṭalamankī en su maŷlis en el año 420/1029 (83).

9) Abū Ayyūb al-Zāhid, de Córdoba, imām de la mezquita alKawwābīn de Córdoba (84).

10) Ahmad b. Ibrāhīm b. Abī Zayd al-Lawātī, de Murcia (m. d. 423/1031). Fue también discípulo de Abū I-Walîd al-Bāŷî (85).

11) Ahmad b. Muhammad b. Harīs, Abū 'Umar (m.h. 400/1009). Transmitió de al-Antākī, libn 'Awn Allāh, lbn Mufarriŷ e lbn al-Nu'mān alMuqri'. Se contaba entre los așhāa de al-Ṭalamankī, quien le concedió la iȳāza (86).

12) 'Alī b. Ahmmad b. Sĩda, Abū I-Hasan. Con al-Talamankī estudió sobre todo hadīt, el Muwatta' y algunos tratados de al-Širāzī sobre dificultades del Corán (87).

13) 'A $\bar{r}$ b. Jalaf b. Batțāl al-Bakrī, Abū l-Hasan, conocido por lbn al-Laḥ̣ām (m. 444/1052). Óriginario de Córdoba, tras la fitna emigró a

(79) Este dato es interesante, ya que este Asbag (m. 299/911 o 304/916) fue un importante asceta cordobés: $v$. mi edición, trad. $v$ estudio de Muhammad $b$. Waḍ̂āh, Kitāb al-bida' (Madrid 1988), p. 61.

(80) D, n० 1125 .

(81) V. al-l'ām bi-man halla bi-Marräkuš, vol. Il (Rabat 1974), p. 19. V. también Deverdun, G., Inscriptions arabes de Marrakech (Rabat 1956), p. 17.

(82) IA(A), n० 2207; IZ, nº 60 .

(83) $\mid A(C), n^{\circ} 2127$.

(84) $\mid A(C), n^{\circ} 535$.

(85) IA (C), n० 112; DT, $/ 11, n^{\circ} 53$.

(86) $\mid A(C), n^{\circ} 30$. Ibn al-Abbär cita a Hātim al-Tarābulusī, quien dijo: "... Yo he visto las clases tomadas por lbn Harǐš con ibn 'Awn Allāh en el mes de safar del año $378 / 988$ junto con Muhammad b. Ahmad al-Talamankī Y Mụhammad b. Bannūš". Adviértase que íon "Awn Alläh murió en ese mismo año.

(87) V. H. Zayyāt, "Urȳūzat gamīs li-l-imām lbn Sĩda sāhib al-Mujașas fĩ I-luga", Al-Mashriq XXXV1 (1938), pp. 181-91, especialmente p. 190, y cf. el estudio ya mencionado de Cabanelas, Ibn Sida, pp. 38-9 y 42-5. 
Valencia. Compuso un gran comentario del Saḥịh de al-Bujārī, así como un Kitāb fīl-zuhd wa-l-raqā'iq (88).

14) 'A $\overline{1}$ b. Sa'īd b. Hazm, Abū Muhammad (m. 456/1064), el gran polígrafo del s. XI perteneciente a la escuela zāhirí. Sería interesante saber qué estudió exactamente con al-Talamankī, además de las tradiciones citadas en el Fișal (89).

15) 'A cargo de cadí. Fue discípulo también de Abū 'Amr al-Dānī (90).

16) al-Hasan b. Muhammad b. Hālis al-Azdī al-Muqri', Abū 'Ali, de Zaragoza. Estudió con el cadí Muhammad b. Ismāin b. Muhammad b. Fūrtiš ( $\left.v . n^{\circ} 25\right)$ el Ta'rī de Ibn Abī Jaytama; por su parte, él enseñó lecturas coránicas. Al-Talamankī le dio la iȳazza en el mes de Safar del año 404/1013. Fue uno de sus așhāb más importantes. Veremos sin embargo que testimonió contra su maestro en el proceso incoado en Zaragoza por jilăf al-sunna (91), lo cual se podría interpretar en el sentido de que las ideas y doctrinas de al-Talamankī habian sufrido una evolución.

17) Hātim b. Muhammad b. 'Abd al-Raḥmān al-Tarābulusī, Abū IOāsim (m. 469/1076). Cordobés, aunque originario de Trípoli en Siria. Hizo la riḩ/a en el año 402/1011, estudiando en Qayrawān con al-Qābisī y con Abū 'Imrān al-Fāsī. Es autor de una Fahrasa(92).

18) Hišām b. Ahmmad b. Jālid b. Hišām al-Kinānī al-Waqqaš̄i, Abū I-Walid (m.479/1086). Nació en Toledo en el año 408/1017, por lo que debió estudiar con al-Talamankĩ antes de los diecinueve o veinte años. Fue un sabio polifacético, experto en diversas ramas del saber como gramática, lexicografía, poesía, ușül al-i'tiqādāt, ușül al-figh, contratos, partición de herencias, geometría .... Fue cadí en Talavera y Valencia (93). Parece que se le atribuyeron opiniones no muy ortodoxas, posiblemente relacionadas con su interés por la lógica y el ka/ām (94).

19) Ibrāhīm b. Mūsà lbn al-Ŷayyāb, Abū Isḥāq (m.d. 448/1056), de Medinaceli. Estudió con al-Talamankī en Zaragoza (95).

(88) TM, VIII, 160.

(89) V. Asín, Abenházam, 1, 100 y v. apartado 1.8., cl.

(90) $\quad\left(A(A), n^{\circ} 2277\right.$.

(91) $\mid A(C), n^{\circ} 678 ; 1 J$, p. 34

(92) IB, n० 351; Fórneas, Elencos biobibliográficos..., p. 16.

(93) Sāaid, Tabaqāt al-umam (trad. R. Blachère, París 1935), pp. 136-7; $D, n^{\circ} 1426$; IB, $n^{\circ}$ 1323; SD, XIX, 134-6; Pons, Ensayo, n' 127; GAL, I, 479 y SI, 662; Menéndez Pidal, R., "Sobre aluacaxi y la elegía árabe de Valencia", Homenaje a D. Francisco Codera (Zaragoza 1904), pp. 393-409.

(94) En IB se dice: "wa-qad nusibat ilay-hi ašyā' Alläh a lam bi-haqiqati-hi wa-sā'iluhu 'an-hã wa-muŷazzi-hi bi-hã"("se le atribuyeron cosas que sólo Dios sabe si son verdad, pues será El quien le preguntará y le recompensará por ellas"). El cadí 'Iyād (apud SD) afirmó que fue sospechoso de mu'tazilismo y que compuso obras sobre al-qadar y el Corán y que las gentes se apartaron de él.

(95) $\mid A(C), n^{\circ} 350$. 
20) 'Tsà b. Muhammad b. Baqī, de Madinat al-Faraŷ (96).

21) Ismā'ī b. Yahyà b. 'Abd al-Rahmān b. 'Abd Allāh, Abū l-Qāsim, conocido por Ibn Fūrtiš (m.h. 500/1106), de Zaragoza y hermano del cadí Muhammad b. Yahyà Ibn Fūrtiš (v. $n^{\circ} 27$ ) y como él asceta. Estudió en La Meca con Abū Darr al-Harawī (97).

22) Muhammad b. Ahmad b. 'Abd Allāh al-Jawlānī: según Ibn alŶazarī transmitió de al-Ṭalamankī por iŷāza (98).

23) Muḥammad b. 'Attāb b. Muḥsin, Abū 'Abd Allāh (m. 462/1069), cordobés de origen mawlà. Fue uno de los alfaquíes y muftíes más importantes de Córdoba, experto sobre todo en formularios notariales (wațá'iq) (99).

24) Muhammad b. 'T̄sà al-Magāmī, Abū 'Abd Allāh (m. en Sevilla en 485/1092i, de Toledo. Fue discípulo de Abū 'Amr al-Dānī y de Makkī b. Abī Tālib (100). La relación con al-Talamankī es mencionada por

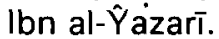

25) Muhammad b. Ismā'Ti b. Muhammad b. Fūrtiš (m. 453/1061), $A b u ̄$ 'Abd Alläh, perteneciente a una ilustre familia de Zaragoza, donde él fue cadí. Estudió con Abū 'Imrān al-Fāsī entre otros maestros de Ifrīqiya (101). Entre sus discípulos se cuentan su hijo el también cadí Abū Muhammad Muhammad y Abū I-Walīd al-Bāŷī (102).

26) Muhammad b. Jalaf b. Sa'T̃d b. Wahb, Abü ‘Abd Allāh, conocido por Ibn al-Murābiț (m. 485/1092). Fue cadí en Almería, su ciudad natal. Estudió también con Abū 'Amr al-Dānī y compuso un Sarh al-Bujārī. Ibn Baškuwāl leyó una copia de la inscripción que se encontraba escrita en su tumba (103).

27) Muhammad b. Yaḥyà b. 'Abd al-Raḥmān b. 'Abd Allāh Ibn Fūrtis, cadí de Zaragoza y hermano del $n^{\circ} 21$ (104).

28) Muhammad b. Yahyà b. Sa'T̃d al-'Abdarī, Abū 'Abd Allāh, conocido por libn Samā'a (m. 472/1079). Fue jațib en Zaragoza, su ciudad natal. Fue enterrado el mismo día y en el mismo lugar que el hijo de Abū I-Walı̀d al-Bāŷī (105).

(96) IA(A), n 2399. Es uno de los transmisores del sueño de al-Talamankī relativo a su propia muerte.

(97) IA(C), $n^{\circ} 481 ; N T, 11,606, n^{\circ} 232$.

(98) No he podido identificarlo. Tal vez sea una confusión por Muhammad b. 'Abd Allāh b. 'Abd al-Rahmmān al-Jawlānī, autor de una Fahrasa: v. Fórneas, Elencos biobibliográficos.... p. 16.

(99) IB, n० 1077; D, n²41; TM, VIII, 131-4. Es citado muy frecuentemente por Ibn Sahl en sus al-Ahkām al-kubrà.

(100) D, n० 216 .

(101) V. Idris, H.R., "Deux maītres de l'école juridique kairouanaise sous les Zïrīdes (le siècle): Abū Bakr b. 'Abd al-Rahmmān et Abū "Imrān al-Fāsī", AlEO XIIl (1955), p. 52 .

(102) TM, VIII, 95; IA(C), n० 1058.

(103) IB, n० 1107; TM, VIII, 184.

(104) D, $n^{\circ} 313 ; N T, 11,606, n^{\circ} 233$.

(105) IB, $n^{\circ} 1088$. 
29) Ṭāhir al-Andalusī, Abū I-Hasan, de Málaga. Era uno de los așhāb de al-Talamankī wa-mulāzimi-hi li-qirā'āt al-Qur'ān. Tras la entrada dé los beréberes en Córdoba en el año 403/1013 abandonó al-Andalus $y$ se estableció en La Meca (106).

30) T̄āhir b. Muhammad b. Tāhir b. 'Abd al-Rahmmān al-Quraš̄̄ alZuhrī, de los descendientes de Abū Salama b. 'Abd al-Rahmān b. 'Awf, Ibn Nāhid; establecido en Zaragoza (107).

31) 'Ubādil b. Muḥammad b. Yahỳà b. 'Ubādil, Abū l-'Ayšs, de Zaragoza, donde estudió con al-Talamankī al-Ahkām (108).

32) Yahyà b. Ibrāhīm b. al-Bayyāz, almocrí discípulo de Abū 'Amr al-Dānī y de Makkī b. Abī Tālib (m. 496/1102) (109). Su relación con al-Talamankī es mencionada por lbn al-ÝYazarī.

33) Yahyà b. Jalaf b. Yahyà b. Jalaf al-Umawi (m.d. 442/1050), de Huesca, establecido en Zaragoza. Fue mušāwar con el cadí lbn Furtūn, pero no se dice que le consultara en el asunto de al-Talamankī (110).

34) Yũsuf b. 'Abd al-Barr, Abū 'Umar (m. 463/1070), el famoso alfaquí mālikí cuya obra es representativa de la influencia ejercida por el saafi'ísmo en la doctrina mālikí (111). En su orientación debieron ser determinantes, entre otras, las enseñanzas recibidas de al-Talamankī con su énfasis en el hadit.

35) $\mathrm{Abu}$ 'Úmar b. al-Harrār, a quien no he podido identificar.

Al pasar revista a los discípulos de al-Talamankī, lo primero que llama la atención es la abundancia de la iŷaza (especie de certificado de estudios que solía implicar licencia para transmitir y enseñar lo aprendido) y que en algunos casos no pudo ir acompañada de trato directo (112). También cabe destacar la importancia que en las enseñanzas de al-Talamankī parecen haber haber tenido las lecturas coránicas. Hay que señalar sin embargo que aquí puede haberse producido un cruce entre "Abū "Umar" al-Talamankī y "Abū "Amr" al-Dānī, facilmente explicable por la similitud de la grafía de sus respectivas kunyas: tal vez los tres

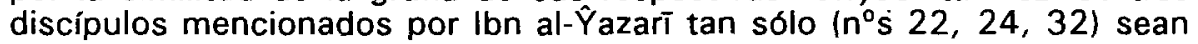

(106) IA(C), n०919; DT, IV, n²91; NT, II, 512-3, n' 201.

(107) $\mid A(C), n^{\circ}$ 918. V. Molina, L. Y Ávila, $M^{*}$ L., "Sociedad y cultura en la Marca Superior" (Historia de Aragón, vol. Ill, Zaragoza 1985, pp. 83-108).

(108) IA(A), n²479. Leo al-Ahkām y no al-lhkām porque creo que se está haciendo referencia a alguna obra de $A h k a ̄ m$ al-Qứān, disciplina en la que era experto alTalamankT. V. al respecto Felipe, E. de y Rodríguez, F., "La producción intelectual māliki a través de al-Dỉbāŷ al-mudhab de Ibn Farhūn" (EOBA I, ed. M. Marín, Madrid 1987, pp. 419-528), pp. 473-4, $n^{\circ} s 23,24,25,27,28,29,30,31$, obras todas ellas de autores anteriores a al-TalamankT.

(109) D, $n^{\circ} 1458$.

(110) IA(A), $n^{\circ}$ 2746. La fuente de Ibn al-Abbār es Ibn Gašilyān, que es el informador acerca de los participantes en el proceso de al-Talamanki.

(111) D, n० 1442; IB(C), n $1501 ;$ TM, VIII, 127; SD, XVIII, 153-63; Pons, $n^{\circ} 111 ; \mathrm{El}$ 2, s.v. (Ch. Pellat).

(112) Este fenómeno ya fue puesto de relieve por Urvoy, op. cit., p. 109. 
en realidad discípulos de al-Dānī y no de al-Talamankī. Entre los ulemas formados por al-Talamankī encontramos ascetas y misticos, tradicionistas $y$ alfaquies. De cuatro se nos informa que se dedicaron a i'tiqādāt $(v$. nota 73) y ușul al-figh $\left(n^{\circ} s 1,14,18,34\right)$ y de esos cuatro, tanto Ibn Hazm como al-Waqqaši fueron sospechosos de heterodoxia.

Cuatro miembros de la familia de los Banū Fūrtiš ( $n^{\circ} s 1,21,25,27$ ) fueron discípulos de al-Talamankī. La importancia de esta familia, en la que abundaron los cadíes ha sido puesta de relieve por $L$. Molina y $M^{a} L$. Avila (113).

1.6. Al-Talamankī es recordado como alfaquí y tradicionista, pero sobre todo como almocrí de gran prestigio (kāna imām fi l-qirāāât). Ibn Baškuwāl precisa: "Era uno de los imames en la ciencia del Corán, sus lecturas, su i'rāb, sus aḥāmm, la ciencia del abrogado y del abrogante, sus significados". Abū "Am̆r al-Dānī, autor de una obra (perdida) sobre

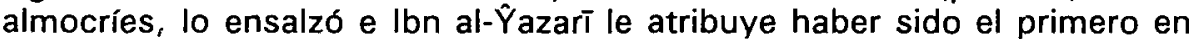
introducir las qirā'āt en al-Andalus. Fue autor de varias obras de estudios coránicos (v. apartado 1.7., $n^{\circ}$ s $1,6,8$ ).

Era asimismo entendido en la transmisión de la tradición profética, es decir, en el conocimiento de las biografías de los transmisores y su grado de veracidad (ma'rifat al-rîyān). Como tradicionista, se le consideraba de confianza (114).

Era experto en los sunan o tradiciones, conocedor de los ușūl aldiyānāt (teología no racionalista) y partidario de los milagros de los santos (muz̧hir li-l-karāmāt). Sobresalió también en su búsqueda del saber no por mera erudición sino por deseo de comprender, pero manteniéndose siempre dentro de los límites de la ortodoxia (talab al- 'ilm, al-ma'rifa wa-l-fahml 'alà hudà wa-sunna wa-istiqãma). Era una "espada desnuda" (qāmi') contra los innovadores (ahl al-ahwā' wa-l-bida'), los sometía, celoso de la Sarīa y sin hacer concesiones en lo que se refiere a la esencia de Dios (šadīd fi $\underline{\text { datt }}$ $A / / \bar{a} h)$. Esta descripción podría ser interpretada en el sentido de que alTalamanki, como los mu'tazilíes, afirmaba que Dios no tenía atributos distintos de su esencia (115). Si ello es así, estaría en contra de la

(113) "Sociedad y cultura", pp. 88-9.

(114) Sin embargo, en TH se recoge un hadīt transmitido por al-Talamankī con el siguiente isnād: Muhammad b. Yahyà b. Mufarrîy - Muhammad b. Ayyūb atȘamūt - Ahmad b. 'Ámr al-Bazzār - Muhammad b. al-Mutannà - Mu'ād b. Hišām su padre - Qatāda - al-Aswad b. Sarī" -el Profeta: "Se presentarán ante Dios el sordo, el tonto, el decrépito ...", explicando al-Dahabī que es garib munqati les decir, raro y con un isnäd interrumpido). Se trata de una de las tradiciones que Ibn Hazm cita en su Fișal como enseñanza de al-Talamankĩ v. apartado 1.8. c).

(115) V. al respecto Watt, W.M., Islamic philosophy and theology (Edinburgo 1962), pp. 63-4: "The Muslims were accustomed to say that God had ninety-nine "beautiful names" ...Some theologians held that God had certain attributes (sifāt) corresponding to these names ... To the Mu'tazilites, however, this seemed to be introducing an element of multiplicity into the unity of the divine nature or essence (nafs, dhāt), and in insisting on "unity" they were asserting that these attributes had no sort of independent or hypostatic existence, but were merged in the unity of God's being". 
doctrina de al-As‘arī (m.324/935) quien sostenía que los atributos divinos, aun no teniendo significación corporal, eran reales si bien su naturaleza exacta es desconocida (116), postura próxima a la de lbn Hanbal y los tradicionistas para quienes las expresiones antropomórficas del Corán debe ser aceptadas sin inquirir acerca de la manera precisa de su existencia (bi-lā kayfa) (117). Sin embargo, nada nos permite suponer que alTalamankī fuese mu'tazilí. Las fuentes insisten en su pertenencia al madhab ahl al-sunna (que nunca se aplicaría a un mu'tazilí) y nos dicen que se ocupó de usūl al-diyānāt, término que suele utilizarse para designar la teología dogmática o no racionalista por parte de los teólogos tradicionistas que buscan así distinguirla del $k a / \bar{m} m$ o teología racionalista (118). Teniendo en cuenta lo que sabemos acerca de su formación, su obra y sus transmisiones, al-Talamankī aparece precisamente como un teólogo no racionalista con posturas similares a las de su contemporáneo oriental alBāqillānī (m. 403/1013), jurista mālikí y teólogo asłarí.

Ibn al-Hașșār al-Jawlānī (apud TM) dijo: "era uno de los piadosos excelentes que se mantenían en el camino recto y seguían la tradición" (kāna min al-fuḍală' al-șâliḥin 'alà hudà wa-sunna). En este sentido hay que recordar su actividad como polemista: fue autor de refutaciones de las doctrinas masarríes y de las opiniones de lbn Abī Zayd al-Qayrawānī relativas a los milagros.

Hay que destacar también su actividad en el campo del ascetismo (119), estrechamente unido a su deseo por hacer vida de ribāt y a su asentamiento en la última etapa de su vida en zonas de frontera (Zaragoza, Talamanca). También hay que relacionarle con el desarrollo del misticismo en al-Andalus, pues hemos visto que aparece en una cadena mística que llega a Ibn al-'Arif. Si por un lado refutó las doctrinas místicas de Ibn Masarra (v. apartado 1.7., $n^{\circ} 5$ ) acusándole de haber pretendido arrogarse la profecía, por otro lado afirmó la posibilidad de la existencia de los milagros de los santos, oponiéndose a la doctrina más estricta de lbn Abí Zayd y apoyando la postura de su maestro el místico Ibn Ŷahdam y de alBāqillānī (120). Se mantuvo por tanto alejado de las doctrinas extremas de los masarries, pero al mismo tiempo fue más allá del ascetismo ya asimilado por la ortodoxia de la época.

Al-Talamankī se nos aparece pues como un ulema distinto del tipo tradicional de alfaquí mālikí de la época, ya que no se ocupó de la literatura

(116) V. El 2, s.v. al-Ash'ari (W.M.Watt).

(117) Watt, Islamic philosophy and theology, p. 80.

(118) Los mutakallimūn, por el contrario, utilizan indistintamente ambos términos: $v$. al respecto Makdisi, G., "Ash'ari and the Ash'arites in Islamic religious history", Studia Islamica XVII (1962), pp. 48 y 50-1. El título de una de las obras teológicas de al-Ash'arī es precisamente al-lbãna 'an ușūl al-diyāna (trad. de W.C.Klein, New Haven 1940).

(119) Ya puesta de relieve por Urvoy, quien la vincula al proceso sufrido por alTalamankĩ: v. op.cit., pp. 147-51.

(120) V. Ibn Hamādī, "Karāmāt al-awliyā" 
de cuestiones jurídicas (masā'in), interesándose por el contrario por nuevas disciplinas: lecturas coránicas, ḥadiț, teología y misticismo.

1.7. Dicen los biógrafos de al-Talamankī que compuso numerosas obras, todas ellas de gran utilidad y en las que mostraba su saber y que dejaban claro su capacidad de comprensión (fahm) (121). Seguía en ellas el madhab ahl al-sunna. Entre sus obras (122) se cuentan:

1) K. al-bayān fi i'rāb al-Qur'ān.

2) K. al-dalī ila ma'rifat al-Ŷli (en 100 yuz'); Ibn Jayr llama a esta

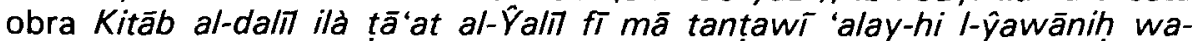
tubāsiru-hu bi-l-'amal al-yawärih/K. yawm wa-layla (123) y la menciona dentro del apartado dedicado a las obras de ascetismo (al-zuhd wa-lraqā'iq wa-mā yattașilu bi-hā). Para hacerse una idea del contenido de esta obra se debe consultar el Kitāb 'amal al-yawm wa-l-layla de Ahmad b. Muhammad al-Dinawarī, conocido por Ibn al-Sinnī ( $m$. 364/974) (124): se trata de una especie de manual para el creyente en el que se recogen tradiciones relativas a todos los actos realizados por el Profeta desde el momento de levantarse al de acostarse, con el objeto de que se intente imitarle dentro de lo posible.

3) Faựa'il Mālik wa-riȳāl al-Muwațta'. Este tipo de obras abunda en el s. $\mathrm{V} / \mathrm{XI}$ y son un intento por poner de relieve la adecuación del Muwatta" a las normas de la ciencia del hadit. A la hora de componer esta obra pudo ser influido por la similar de su maestro al-Ŷawharī (v. apartado 1.3., $\left.n^{\circ} 2\right)$.

4) Fahrasa (125). Abū 'Umar al-Talamankī es citado en algunos diccionarios biográficos (es el caso de la Sila de Ibn Baškuwāl (126) y de al-Dahabī (127)) como transmisor de noticias referentes a ule-

(121) Creo que este término se utiliza con el mismo significado que dirāya como antónimo de riwāya: $v$. Fierro, $\mathrm{M}^{\star} \mathrm{l}$., "Obras $\mathrm{y}$ transmisiones de hadit (ss. $\mathrm{V} / \mathrm{X}$ )VII/XIII) en la Takmila de Ibn al-Abbär" (Valencia 1990), p. 222.

(122) IJ, I, 443-4, habla de tawālit.

(123) V. Fahrasa, p. 288. En la biografía que el cadi "lyād dedica a Sulaymān b. Battāl al-Batalyawsī, se recoge que este ulema (m. 402/1011) compuso entre otras

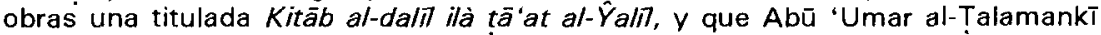
llamó de la misma manera uno de sus libros (wa-bi-mitli hādā l-ism summiya aydan Abū 'Umar al-Talamanki kitāba-hu l-kabir): TM, VIII, 30. Abū Nu'aym alIsfahānī y al-Nasā'î fueron autores de obras tituladas también Yawm wa-layla: v. Ibn al-Abbār, al-Mu'ỹam fi ashāa Abi 'Alí al-Sadafí led. F. Codera, Madrid 1886, BAH (V), pp. 311 y 316.

(124) Editado por Sālim b. Ahmad al-Salafī, Beirut 1988.

(125) Asi llamada en IJ, pp.430-1. También se le llama Barnāmaŷy parece que lo puso por escrito Hātim al-Tarābulusĩ: $v$. una cita en $(A(A) ; 2611$.

(126) V. De Felipe, H. Y N. Torres, "Fuentes y método historiográfico en el Kitāb al-sila de Ibn Baškuwāl" (EOBA III, pp. 307-34), p. 333. Las ocasiones en que Ibn Baškuwāl utiliza como fuente a al-Talamanki son: $\mid B(C), n^{\circ}$ s $30,57,763,851$.

(127) Es el caso de SD, XVI, 523 (citado en 1.3., $n^{\circ}$ 8); XVIII, 144-5 lanécdota referente a lbn Sida) y XV, 556-8. Esta última referencia la tomo de Castilla, J., "Las fuentes de al-Dahabi" (EOBA III, pp. 351-60), n 14. 
mas, algunos maestros suyos o contemporáneos. Posiblemente esta información proceda de su Fahrasa.

5) K. al-radd 'alà Ibn Masarral Kitāb al-radd 'alā l-bātiniyya (128). Precisa al-Dahabì en los Siyar que en esta obra decía que entre los bāținíes se cuentan gentes que se consagran al servicio de Dios sin conocimiento; pretenden que ven el Paraíso todas las noches, comen de sus frutos $y$ las huríes vienen a visitarlos en sus casas; que esos bāținíes buscan refugio en el trono y ven a Dios sin intermediario y tienen trato con él. Al-Dahabī cita también esta obra de al-Talamankī en la biografía que dedica al andalusí Wahb b. Masarra al-Hiŷāīi (m. 346/957), al que confunde con el bātiní cordobés Muhammad b. 'Abd Allāh b. Masarra(129). La cita es la siguiente: "Dijo al-Ṭalamankī en su refutación de los bāținíes: 'Ibn Masarra se arrogó ser profeta y pretendió haber recibido una revelación, convenciéndose a sí mismo de que procedía de Dios' (qāla al-Talamanki fi raddi-hi 'alà l-bātiniyya: Ibn Masarra idda'à alnubuwwa wa-za'ama anna-hu sami'a l-kaläm fa-tabata fi nafsi-hi anna-hu min 'inda $/ / \bar{a} h)(130)$.

6) Rawdat fi l-qirā'āt al-ihdà 'ašra (131).

7) K. fi l-sunna (en dos tomos). Había en este libro, según SD, cosas con las que nunca se podría coincidir con él como en el bāb al-ŷanb li-l/āh, donde reproducía la aleya $X X X \mid X, 57 / 56$, que reza: "... antes de que el alma diga: "¡Qué desgracia la mía por haber sido negligente en el servicio de Dios, yo que estuve entre los burlones!" (an taqūlu nafs ya hasratà 'alà $m \bar{a}$ farrațtu fì ŷanbi Al/āh). Interpreto que al-Talamankī decía que ése era el error (zalla) de un sabio.

8) Tafsir al-Qur'ān (100 ŷuz') (132).

9) Risāla fĩ ușül al-diyānāt ilà ahl Ušbūna.

10) y 11) K. al-wușül ilà ma'rifat al-ușül fi masā'il al-'uqūd fi lsunna ("Libro de la consecución del conocimiento de los fundamentos en las cuestiones de las creencias en la Tradición"l, así como su $K$. al-r. almujtasara fī mad̄āhib ahl al-sunna wa-dikr mā daraỹa 'alay-hil-șahāba wal-tābi ün wa-jiyār al-umma ("Libro de la epistola resumida sobre las doctrinas de las gentes de la Tradición y mención de cómo procedían los Compañeros del Profeta, los Sucesores y los mejores de la comunidad"). Estas dos obras son citadas por Ibn Jayr en el apartado dedicado a los kutub ușül al-dīn wa-ușül al-fiqh wa-faụl al-‘ilm wa-gayr dãlika mimmā

(128) V. Asin Palacios, Abenmasarra, p. 90, nota 2; Fierro, Heterodoxia, pp. 139, nota 52.

(129) Ya tuve ocasión de señalar esta confusión en un trabajo anterior, realizado conjuntamente con J. Zanón, "Andalusies en dos obras de al-Dahabĩ: Siyar a'ām al-nubalä' y Tadkirat al-huffäz" , EOBA I (ed. M. Marín, Madrid 1988, pp.183233), p. 187.

(130) SD, XV, 558.

(131) Citada por Hāŷȳ Jalifa, Kašf al-zunün (ed. G. Flügel, 7 vols. en 4, Leipzig 183558), III, 510 y por Ibn al-Ŷazari.

(132) Un fragmento de esta obra se conserva en el Vaticano: v. GAL, SI, 729. 
yattașilu bi-hi (133). Nos gustaría poder precisar su contenido; por sus títulos parece claro que la doctrina de al-Talamankī se remitía siempre al ejemplo del Profeta y las generaciones salaf.

12) El cadí 'lyāọ menciona a Abū 'Umar al-Talamankī entre quienes escribieron refutaciones contra las doctrinas de Ibn Abi Zayd al-Qayrawānī (134) relativas a las karāmāt y a la nubuwwa de las mujeres, citando el siguiente pasaje: "Dijo al-Talamankī: "Estas (opiniones) de Abū Muhammad (b. Abi Zayd) fueron un desatino para el que sin embargo hubo sus razones, pues lo hizo necesario la pugna/antipatía que se habla producido entre los ulemas. Tenemos la seguridad de que se retractó de esas opiniones. El no quería aparentemente más que fortificar la profecía, pero acabó ignorando los milagros o carismas al insistir en presentar sus puntos débiles. En cualquier caso, él es el más ilustre de los que reprobaron los milagros con una reprobación que implicaba su negación. Por lo que ha llegado hasta nosotros, los reprobó basándose para dicha censura en generaciones en las que había habido quienes hicieron uso de esos milagros como estratagemas para hacerse con el dinero de las gentes y que trataban de engañar a los ignorantes ..." (135). En el siglo $\mathrm{V} / \mathrm{XI}$ hubo polémica acerca de cuáles eran las criaturas más excelentes, planteándose en especial la cuestión de la excelencia relativa de los santos y los profetas (136). Ibn Hazm acusó a los as'aríes de afirmar que los milagros del Profeta no son prueba de la veracidad de su misión profética (137).

De las doce obras mencionadas hasta ahora, tres son de ciencias coránicas $\left(n^{\circ} \mathrm{s} 1,6\right.$ y 8$)$; una versa sobre ascetismo $\left(n^{\circ} 2\right)$; una relacionada con el mālikismo ( $\left.n^{\circ} 3\right)$; cuatro parecen versar sobre teología (usūl al-dīn) $\left(n^{\circ} 7,9,10\right.$ y 11$)$; dos son obras de refutación $\left(n^{\circ} 5\right.$ y 12) y un repertorio bibliográfico $\left(n^{\circ} 4\right)$.

Hay referencias a la existencia de otras obras.

E. Terés parece señalar una obra de al-Talamankī manuscrita en la "Colección Gayangos" (138), pues al mencionar el ms. $\mathrm{n}^{\circ}$ XVIII dice: al-Durr al-nafís, sin nombre de autor: es una refundición de Futūh al-Sām ..., obra falsamente atribuida a al-Wãqid̄, con otra obra de asunto análogo compuesta por Abū 'Umar al-Talamankī...". No he podido consultar el ms.

(133) IJ, p. 259

(134) TM, VI, 219-20 y v. Idris, "Deux juristes", pp. 146-9, 154, 159. Los otros autores de refutaciones de Ibn Abi Zayd mencionados por 'lyād son: Abū I-Hasan b. Ŷahdam al-Hamdānī, al-Bāqillānĩ y el andalusí Abū 'Abd al-Rahmān b. Šaqq al-Layl.

(135) V. el artículo citado en la nota 1 de lbn Hamādi, "Karāmāt al-awliyā'".

(136) Esta polémica se puede ver en Ibn Hazm, Fisal, IV, 150, 169 y V, 2-11, 14-8; trad. Asín, Abenházam, V, 88, 138, 147-75, 182-4.

(137) V. Fiṣal, IV, 164, trad. Asín, Abenházam, V, 124.

(138) V. su trabajo "Los manuscritos árabes de la Real Academia de la Historia: la Colección Gayangos", Discurso leído en el acto de su recepción pública (Madrid 1975), p. 39 . 
F. Codera, al reseñar el contenido e importancia del diccionario biográfico contenido en un ms. del Museo Jalduní de Túnez (139), indica que en el apartado dedicado a al-Talamankī se encuentra la relación más completa de sus obras que él ha visto, pues consta de 19 títulos, mencionando a modo de ejemplo la titulada Kitāb fî-hi risāla su'ila 'an-hā ba'd man fi tagr Lãrida. Traduce Codera dicho título como "un libro, en el cual (hay) una risala acerca de la cual fue interrogado uno 6 unos de los que estaban en la frontera de Lérida", pero creo que la traducción es "epístola solicitada por algunos de los que estaban en la frontera de Lérida". Posiblemente algunos musulmanes que hacían vida de ribāt en dicha frontera le escribieron solicitando su consejo o su saber. Recuérdese que la obra $n^{\circ} 9$ es también una epístola dirigida en ese caso a las gentes de Lisboa.

\subsection{Entre sus transmisiones se cuentan:}

a) obras sobre el Corán como

- K. al-waqf wa-l-ibtidā' de Abū Bakr b. al-Anbārī, en la riwāya de Abū Sahl al-Bagdãdī y en la de lbn al-S̄ã 'îī (140).

b) obras de historia como

- K. sīrat rasūl Allāh de Ibn Hišām (141);

- Tabaqāt 'ulamā' Ifrīqiya wa-Tūnis de Abū l-'Arab Muhammad b. Ahmad al-Tamīmī (m. 333/945). La edición realizada por M. Ben Cheneb (Argel 1914) se basa en un ms. argelino único que habría pertenecido a alTalamankī y que conserva sus anotaciones (142).

c) obras de hadit y figh como

- Kitāă al-išrāf 'alà madāhib ahl al-'ilm fî l-iŷtimā' wa-l-ijtilāf de Abū Bakr al-Nīsābūrī (143);

- K. al-'ayn de Ibn Sanŷar (144);

- K. fi-hi min hadīt al-'Abbās b. al-Walīd al-Qāḍi (145);

(139) V. su artículo citado al final de la nota 2.

(140) IJ, p. 45.

(141) IJ, p. 235; Gunya, p. 125, así como Jarrar, M., Die Prophetenbiographie im islamischen Spanien: ein Beitrag zur Uberlieferungs und Redaktionsgeschichte (Frankfurt 1989), pp. 264 y 291.

(142) V. la introducción a la traducción anotada (Argel 1920), p. VI, así como la nueva edición de 'ATI al-Šābbī y N. Hasan al-Yāfī (Túnez 1968), p.28 y p. 30, donde se señala que la obra conservada es en realidad un Mujtasar realizado por alTalamankī y que éste regaló su ejemplar a al-Jušanī (m. 371/981). Recuérdese (v. apartado 1.2.) que al-Talamankī parece haberse ganado por esas fechas la vida en Córdoba como copista.

(143) Ibn 'Atiyya (m. 541/1147), Fihris (ed. M. Abū l-Aŷfān y M. al-Zāhī, Beirut 1400/1980), p. 102.

(144) IJ, p. 142.

(145) IJ, p. 176. 
- K. al-arba'īn de al-Āŷurrī (146);

- K. al-sunna de al-Bāzarnī al-Kātib (147);

- al-Muwatta' de Mālik (148);

- Musnad hadít Mãlik de al-Ŷawharí (149); Fișal (150).

- tradiciones enseñadas a lbn Hazm y citadas por éste en su

d) obras de zuhd como son

- K. al-'arūs fĭl-zuhd, de Abū Bakr Ahmad b. Muhammad b. al-Faḍl al-Ahwāzī (151):

- K. al-zuhd de Abū Bakr b. Rizq (152);

- al-Maw'iza de Wahb b. Munabbih (153);

- al-Risāla ilà Hārūn al-Rašid de Mālik;

- al-Risāla ilà al-Layt b. Sa'd de Mālik;

- Ŷawāb li-risālat Mālik de al-Layt (154).

- Tawālif del asceta y místico Âbū Sa'īd b. al-A'rābī, maestro de maestros suyos (155).

e) obras de gramática y adab como

- al-Garīb al-mușannaf de Abū 'Ubayd al-Oāsim b. Sallām al-Harawī (m. 224/839) (156);

Šìāzì (157):

tratados sobre dificultades del Corán (muškil al-Qur'ān) de al-

- K. al-ŷumal de al-Zaŷŷāŷi (158);

(146) V. IB, $n^{\circ} 851$ y 1.2., $n^{\circ} 16$.

(147) V. $\mid A(C), n^{\circ} 790$ y $1.2 ., n^{\circ} 7$.

(148) V. Cabanelas, Ibn Sida, p. 44, citando la urŷūza de Ibn Sīda editada y estudiada por Zayyāt, p. 190, así como el Fihris de Ibn 'Atiyya y la Gunya del cadí 'lyāọ (ed. M. Zuhayr Yarrār, Beirut 1402/1982).

(149) Ibn 'Atiyya, Fihris, p. 101.

(150) V. la edición de El Cairo 1347, IV, 10, 25,66, 106 y v. la traducción de Asín Palacios en Abenházam, IV, 173 (omite el pasaje), 179, 245 y V, 18 (omite el pasaje). $V$. la nota 114.

(151) IJ, p. 297.

(152) IJ, p. 276.

(153) IJ, p. 294.

(154) Para estas tres últimas, v. IJ, p. 298. Para la correspondencia entre al-Layt y Mālik v. Brunschvig, R., "Polémiques médiévales autour du rite de Mălik", AlAndalus XV (1950), pp. 377-435.

(155) V. IJ, I, 438.

(156) Ya hemos visto que enseñó este libro en Murcia. V. Cabanelas, Ibn Sida, pp. 113-4 con una descripción de la estructura y contenido de la obra. $V$. también "Iyād, Gunya, p. 9.

(157) V. Cabanelas, Ibn Sída, p. 45, citando la urȳūza de lbn Sīda editada por Zayyāt, p. 190. No he seguido la traducción de Cabanelas ("tratados de metáforas").

(158) IJ, p. 308. 
- al-Nawādir de Ibn Miqsam (159);

- K. 'uqală' al-maŷānīn de Abū Bišr al-Dawlabī (160).

f) obras de diversos autores:

- Tawāliff de 'Abbās de Aṣbag, su maestro (161); tro $\{162\}$

Tawālif de Muhammad b. Ahmmad b. Mufarriŷ, su maes-

- Tawāl/f de Ahmad b. 'Awn Allāh, su maestro (163);

- Kutub Ibn al-Mundir (164);

- al-Ahkām: v. apartado 1.5., $\mathrm{n}^{\circ} 31$.

1.9. Tenemos noticia de dos hijos suyos. Uno llamado Abū Bakr Muhammad (165), cuya madre era la sobrina (hija del hermano) de Ibn 'Awn Allāh, con la que Abū 'Umar se casó durante su estancia en Córdoba. Este Muhammad estudió con lbn 'Awn Allāh, 'Abd Allāh b. Muhammad b. Qāsim al-Qala'ī (v. apartado 1.2., $n^{\circ} 3$ ) y otros. Ibn Mufarriŷ (v. apartado 1.2., $n^{0} 13$ ) le dio la iŷāza, así como Abū 1-Hasan b. Muŷāhid b. Așbag al-Baŷŷānī y Abū Yahyà Zakariyyā' b. Jālid b̆. Sāhib al-șalāt (v. apartado 1.2., $n^{\circ} 20$ ), este ültimo en el año 403/1012. Como se ve, compartió con su padre muchos de sus maestros. Estudió el Corán y el hadīt. Abū 'Abd Allāh b. al-Sallām le pidió que le diese la iỹāza de todo aquello que le había transmitido su padre y de las obras de éste y así lo hizo. Había nacido en $367 / 977$ y murió antes del año $430 / 1038$. Ibn alAbbār leyó la fecha de su nacimiento escrita por Abū 'Abd Allāh Muhammad b. 'Abd al-Raḥmān b. Sam'ān al-Tagrī.

El otro hijo de al-Talamanki se llamaba 'Abd Allāh (166), de quien nos dice lbn Baškuwāl que transmitió mucho de su padre.

\section{El proceso.}

Debemos la información acerca del proceso a que fue sometido alTalamankī a Ibn al-Abbār (167), quien tomó la información de los fawā'id de Abū l-Hakam 'Abd al-Rahmān b. 'Abd al-Malik b. Gašilyān (m. $541 / 1146)$ (168). Por al-fawā'id creo que hay que entender las

(159) IJ, p. 381.

(160) IJ, p. 409.

(161) V. 1.2., $n^{\circ} 1$ e IJ, I, 443.

(162) V. 1.2., n 11 e IJ, I, 442.

(163) V. 1.2., $n^{\circ} 4$ e IJ, I, 442.

(164) V. 1.3., $n^{\circ} 6$ e IB, $n^{\circ} 92$.

(165) $\mid A(C), n^{\circ} 1075$; otros datos en $\mid A(C), n^{\circ} 30$.

(166) V. IB(C), $n^{\circ} 593$.

(167) Ibn al-Abbãr es citado a su vez en SD, XVII, 568-9.

(168) V. sobre este personaje $D, n^{\circ} 1031 ; I B, n^{\circ} 750 ;$ Ibn al-Abbãr, Mu'yam, $n^{\circ} 215$; 
anotaciones hechas por Ibn Gašilyān a su propia Fahrasa. Posiblemente, al mencionar a al-Talamankī, debió insertar una nota dando noticia del proceso al que fue sometido en Zaragoza con especificación de los nombres de los ulemas involucrados. Sabemos que Ibn Gašilyān había copiado el acta en la que se desestimaban las acusaciones contra alTalamankī, copia que fue consultada por Ibn al-Abbār (169). El método seguido por lbn al-Abbār (170) es dar una entrada biográfica a cada uno de los ulemas mencionados por lbn Gašilyān, de los que doy luego una relación.

2.1. Según la información de que disponemos, al-Talamankĩ fue procesado (umtuhina) por el exceso de su reprobación, es decir, por excederse en el número de las cosas que consideraba censurables y por la intensidad con que las reprobaba (/i-fart inkāri-hi; kāna za'ran fi inkār almunkar) y por jilāf/mujālafat al-sunna. Ún grupo de sus enemigos se alzó contra él, testimoniando en su contra que era harūrī y yarà wad" al-sayf fī sālihì /-musliminial-nās.

Veamos cada una de estas acusaciones.

La acusación de jiläf/mujālafat al-sunna es una acusación genérica que apenas brinda información acerca de las cuestiones que estaban en juego. En efecto, viene a equivaler a la acusación de "innovador" (mubtadi'), pues es "innovador" todo aquel que va en contra de la tradición (sunna) (171). Hemos visto (apartado 1.6.) que al-Talamankī es presentado por las fuentes como una "espada desnuda" contra los innovadores. La acusación de incurrir en "innovación" se puede formular desde todos los puntos de vista(172), en este caso por al-Talamanki contra sus adversarios y por los adversarios contra al-Talamankī. Las otras acusaciones nos ofrecen mayor información.

Se denomina harūrī a quienes se reunieron en Harūrā' (173) en el año 37/657 de entre aquellos partidarios de "Ali que se habían negado a aceptar el arbitraje propuesto por Mu'āwiya en Siffīn y cuyo "programa" consistía en proclamar que la bay'a o juramento de fidelidad debía hacerse a Dios y al precepto de al-amr bi-l-ma'rüf wa-l-nahy 'an al-munkar; también consideraban que el jefe de la comunidad debía ser elegido por una suurà lo consejo consultivo) y ser el mejor musulmán. Asimismo, afirmaban que la participación en el asesinato de 'Uțmān estaba justificada dado que el tercer califa había incurrido en innovaciones; también estaba justificado haber derramado la sangre de Talha, al-Zubayr y sus partidarios el día de

IJ, p. 434; Pons, $n^{\circ} 167$ y p.405. De Zaragoza, pero muerto en Córdoba, fue autor de una Fahrasa.

(169) V. 2.3., final.

(170) V.el estudio de Ávila, Ma L., "El método historiográfico de lbn al-Abbār", EOBA.l, pp. 555-83.

(171) V. Ibn 'Abd al-Barr, Ỹāmi' bayān al-'ilm (2 vols. en 1, Beirut 1398/1978), II, 195.

(172) V. mi edición, trad. y estudio del Kitāb al-bida' de lbn Waḍdāh (Madrid 1988), pp. 92-119.

(173) V. El 2, s.v. (L. Veccia Vaglieri). 
la batalla del Camello, así como la sangre de los partidarios de Mu'āwiya por tratarse de rebeldes y de transgresores del Libro de Dios y de la sunna del Profeta. Puesto que dicha conducta estaba justificada, 'A haber aceptado el arbitraje, sino que debería haber continuado la lucha hasta el final. Ante el argumento de que el propio Corán menciona la necesidad de recurrir a árbitros en algunos casos (IV, 39/35 y V, 1-3/1-2), ellos replicaban que todas aquellas cuestiones para las que existe una decisión (hukm) por parte de Dios no pueden ser sometidas a arbitraje y que Dios ha dejado muy claro cuál debe ser la conducta con los rebeldes en Corán XLIX, 9: "Si dos grupos de creyentes se combatiesen, jimponed la concordia entre ambos! Si uno de ellos persistiese en contra del otro, ¡combatid al que persiste hasta que se incline delante de la orden de Dios!" (174), así como en Corán VIII, 40/39: "Combatidlos hasta que no exista tentación y sea la religión toda de Dios!". Puesto que Mu‘āwiya ni se había arrepentido ni vuelto a la obediencia de Dios, estaba claro que se le debían aplicar esos versos del Corán, entendidos como hukm de Dios con respecto a ellos. $Y$ los hombres no pueden cambiar el juicio de Dios $(/ \bar{a}$ hukma illā li-llāh) (175). En suma, los harūríes se caracterizaron por su actitud rigorista en lo relativo al imāmato.

La segunda acusación formulada contra al-Talamankī está en estrecha relación con la de ser harūrí. Al decir que propugnaba que se debia dar muerte a los musulmanes "virtuosos" (șäliḥün), tal vez lo que se quiere decir en realidad era que él propugnaba que se debía dar muerte a una serie de personas que para al-Talamankī eran pecadores, pero que eran vistas por los demás $y$, en concreto, por sus acusadores como virtuosas. Lo que no queda claro es si la referencia es al pasado (es decir, 'Uțmān, Talha, Mu'āwiya, etc.) o también al presente (es decir, algunos de los reyes de taifas y/o alfaquies, por ejemplo (176)). Otra posibilidad es que propugnase combatir a los malvados (innovadores o infieles) sin conceder importancia al hecho de que durante el combate se podía dar muerte a gente virtuosa.

En suma, se le vino a acusar de seguir las doctrinas de los primeros jāriŷíes en lo que a su rigorismo se refiere, consistente sobre todo en propugnar que se diese muerte a aquellos musulmanes que él consideraba habían incurrido en rebeldía contra Dios. Pero antes de analizar lo que de verdad pudo haber en estas acusaciones, veamos quiénes fueron los participantes en el proceso.

(174) Trad. J. Vernet (Madrid 1963).

(175) V. Hawting, G., "The significance of the slogan lā hukm illā lilläh and the references to the hudūd in the traditions about the fitna and the murder of "Uthmān", BSOAS 41 (1978), pp. 452-63.

(176) Cf. apartado 2.2., $n^{\circ} 4$, de dónde tal vez podría deducirse que había desautorizado a los poderosos de su época como kuffār (infieles) o como mubtadíün (innovadores). De un contemporáneo suyo, el masarri Ismā'il al-Ru'aynī, se decía que "consideraba la tierra toda como tierra de infieles cuya sangre era, por tanto, lícito derramar": v. Ibn Hazm, Fișal, IV, 151, trad. Asín, Abenházam, V, 93 y cf. Fierro, Heterodoxia, pp. 167-8. 
2.2. Sabemos que los testigos contra al-Talamankī fueron quince, contándose entre los alfaquíes y las gentes ilustres (nubahā) de Zaragoza. Estos testigos le acusaron ante el cadí de Zaragoza, Muhammad b. 'Abd Allāh b. Furtūn, Abū 'Abd Allāh (177), en el año 425/1033, diciendo que era harūrī, saffāk al-dimā' (derramador de sangre) y que wada 'a l-sayf (fi) (178) șālihí l-muslimina. La forma más frecuente de hacer referencia a las acusaciones por ellos lanzadas es la de que testimoniaron contra al-Talamankī acusándolo de jilāf/mujālafat al-sunna. Se nos han conservado los nombres de algunos de ellos.

1) al-Hasan b. Muhammad b. Hālis al-Azdī al-Muqri', Abū 'AT̄, de Zaragoza, de quien ya hemos hablado como discípulo de al-Talamankī.

2) Ibrāhīm b. 'Ísà b. Muzāhim al-Umawī, de Zaragoza. Actuó como muftí y testigo en el asunto de al-Talamankī (179).

3) Ismā'i b. Ahmad b. al-Mu'allim al-Darrāŷ, de Zaragoza(180).

4) Muḥammad b. Rāfi“ b. Girbīb al-Umawī, de Zaragoza. Su acusación fue también de jilâf al-sunna, motivada porque al-Talamankī se había mostrado inflexible con la gente de su época y de otras épocas y porque les había aplicado un nombre (181) (¿kuffār?, ¿mubtadi'ūn?) que les movió a perseguirle (wa-dālika li-tašaddudi-hi 'alà ahl 'așri-hi wagayri-him wa-ițlāqi-hi 'alay-him mā haraka-hum li-muțà̀labati-hi) (182).

5) Rāfi‘ b. Nașr b. Girbīb, sobrino (hijo de un hermano) del anterior. Si l lbn al-Abbār le dédicó una biografía independiente, no se ha conservado (183). Aparece mencionado en las biografías de otros de los acusadores (184), ya que éstos se reunieron en su casa y allí escribieron el documento en el que consignaron sus testimonios.

6) Sawwār b. Muḥammad b. Sawwār, de Zaragoza (185).

7) Yahyà b. Muhammad b. Hālis (hermano de al-Hasan) (186).

Poco es lo que podemos deducir del material biográfico acerca de los acusadores de al-Talamankī. De los siete nombres que conocemos, tres $\left(n^{\circ} s 2,4,5\right)$ llevan la nisba "al-Umawī", tratándose con toda probabilidad de mawlàs de los omeyas.

(177) IA, $n^{\circ} 420 ; \mid A(C), n^{\circ}$ 1071. Ibn at-Abbār especifica que no sabe que tenga riwāya: parece que se le recuerda tan sólo por su participación en el asunto de al-Talamankī.

(178) En el texto 'alà (1A, $\left.n^{\circ} 420\right)$.

(179) $\mid A(C), n^{\circ} 345$.

(180) $\mid A(C), n^{\circ} 472$.

(181) Para esta traducción me baso en Dozy, R., Supplement aux dictionnaires arabes (Leiden 1881), s.V.

(182) IA, no 421; |A(C), $n^{\circ} 1072$.

(183) Su biografía está recogida en $\mid B(C), n^{\circ} 427$, razón por la cual lbn al-Abbār no debió considerar necesario repetirla en la Takmila.

(184) V. $\left|A(C), n^{\circ} 472 ;\right| A, n^{\circ} 421 ; \mid A(C), n^{\circ} 1072$.

(185) IA(A), $n^{\circ} 2669$.

(186) $\mid A(A), n^{\circ} 2748$. 
2.3. Los testimonios fueron presentados al cadí Ibn Furtūn, quien testificó ante sí mismo que los testigos debían ser rechazados lashada 'alà nafsi-hibi-isqāt al-suhūd), desestimó sus testimonios, "aunque eran quince de entre los alfaquíes y los nubahā' de Zaragoza", sometiendo a ese grupo, lleno de indignación por lo que le habían hecho a al-Talamankī y exculpándolo de lo que le habían acusado y atribuido; certificó esto bajo su responsabilidad (wa-asŷala bi-dălika 'alà nafsi-hi) en el año 425/1034 (187).

La decisión del cadí estaba respaldada por los dictámenes emitidos por los alfaquíes mušāwarūn consultados, que declararon falsos los testimonios emitidos contra al-Ṭalamankī acusándolo de ser mujālif alsunna y de harūri 'alà jilāf al-sunna. Estos alfaquies fueron: $z a(188)$.

1) 'A íbd Allāh b. Sa'îd b. 'Abd Allāh al-Lajmī, de Zarago-

2) 'Abd Allāh b. Tābit b. Sa‘īd b. Tābit b. Qāsim b. Tābit b. Hazm,

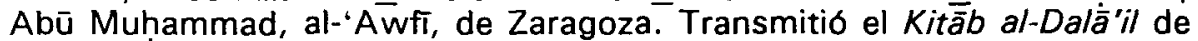
su antepasado Qāsim b. Tābit (189). El texto árabe dice: "šâwara-hu l-qãdi ... fïmā suhida bi-hi 'alà ... al-Talamankì min kawni-hi harüriyyan 'alà jilāf al-sunna fi ŷamà'a ma'a-hu kàna huwa ra'sa-hum wa-șadra-hum wa-l-musammà fi-him awwal al-yamā"a". No acabo de ver claro a quien se refiere la última parte. Ibn Hamāờ la refiere a Ibn Tābit, es decir, Ibn Tābit habría estado al frente dél grupo de los consultados, siendo su jefe y el primero de ellos; en otras palabras, habría sido el jefe de la súrà, pero ¿por qué no llamarla así y utilizar en cambio al-yamā'a? La interpretación correcta en mi opinión es que la última parte se refiere a al-Talamankī, por lo que hay que traducirla de la siguiente manera: "El cadí lbn Furtūn consultó a Tābit en lo referente a la acusación que se había formulado contra al-Talamankī de ser harüri contrariamente a la sunna y de estar al frente de un grupo que había con él, siendo él su jefe y llamándosele el primero de la comunidad". Las implicaciones doctrinales de esta segunda posibilidad saltan a la vista y sobre ellas hemos de volver. Este 'Abd Allāh desestimó los testimonios de los que se habían confabulado contra alTalamankī (190).

3) 'Abd al-Șamad b. Muhammad b. Jașib, de Zaragoza (191). za (192).

4) Muḥammad b. Yaḥyà b. Muḥammad al-Tuŷî̉ī, de Zarago-

(187) |A, n 420; |A(C), n $n^{\circ}$ 1071. V. también |A(C), n० 472: "fa-asqata šahādata-hum wa-saŷyala 'alà nafsi-hi bi-dălika" en el mes de ŷumādà al-ūlà de ese año, así como $\mid A, n^{\circ} 421$ e $\mid A(C), n^{\circ} 1072$.

(188) (A(C), no 1960 .

(189) $V$. sobre esta importante familia de la Marca Superior, de origen beréber, Molina y Ávila, art. cit., pp. 89-91.

(190) |A, $n^{\circ} 1292 ; \mid A(C), n^{\circ} 1954$.

(191) $\mid A(A), n^{\circ} 2160$.

(192) |A, n०425; |A(C), $n^{\circ} 1076$. 
5) Sa'îd b. Muhammad b. 'Abd al-Rahīm, de Zaragoza (193).

6) Yūnus b. Yũsuf b. Muhammad, de Zaragoza (194).

Recuérdese lo dicho respecto al personaje citado en el apartado 1.5., $n^{0}$ 33. También hay que mencionar a Husayn b. Ismā'i b. Husayn alGifārī, de Zaragoza y uno de sus suhūd (testigos profesionales). Ibn alAbbār vio su nombre con la letra de Abū I-Hakam b. Gašilyān "en la copia del documento en el que se dejaba constancia del veredicto de inocencia de Abū "Umar al-Talamankī y de la desestimación de los testimonios de quienes le habían atribuido ir en contra de la Tradición" ( $f$ i nusjat al- agd al-murtasam bi-barā'at Abi 'Umar al-Talamankí wa-isqāt šahādat allādiña nasabū-hu ilà mujālafat al-sunna) (195).

En 425/1034 era señor de Zaragoza Yahyà b. Mundir al-Tuŷibī (412/1021-427/1036) (196); su hijo Mundir, èl futuro Mundir II Mu'izz al-Dawla al-Manșūr (asesinado en 430/1038), aparece en las monedas desde 419/1029, posiblemente al ser nombrado sucesor. En las monedas acuñadas en 419/1029 los tuŷibies reconocen al califa 'abbāsí; en 423/1032 reconocen al omeya Hišām III al-Mu'tadd bi-llāh refugiado en Lérida; durante el reinado de Mundir II las monedas no mencionan a ningún califa. Se pregunta Viguera: "¿Quiso desprenderse incluso de este símbolo de dependencia? Acaso pueda relacionarse todo ello y en esta línea entenderse que la causa manejada por su asesino fuera que Mundir no reconocía al falso Hišam II proclamado como tal por la taifa de Sevilla".

2.4. Los autores que se han ocupado de este proceso han vertido diversas opiniones al respecto.

Asín (197) dice escuetamente: "Parece que fue perseguido por su doctrina teológica, análoga a la de una herejía jāriŷí, en Zaragoza, donde pasó los últimos años de su vida".

Por su parte, Urvoy da una información bastante confusa acerca del proceso contra al-Talamankĩ; su interpretación parece centrarse en la actividad intelectual de al-Talamankī. Así, dice (los puntos interrogativos son míos): "... de son séjour en Orient, al-Talamankī a ramené certaines idées sur le fiqh (?) (on sait par ailleurs qu'il s'agit de son intérêt pour les ușül et dont témoigne son wușül ilà ma'rifat al-ușūh qui ont scandalisé certains fuqahā' de Saragosse, lors de son séjour dáns cette ville. Ceux-ci, au nombre de quinze (et dont la Takmila désigne nomément neuf (?), plus un indirectement, par consultation (?)), lui intentèrent un procès pour être "sorti de la communauté" (?). Contre ces accusateurs, se dressèrent d'autres fuqahā' de la ville, et le cadi de celle-i déclara al-Talamankī inno-

(193) IA(A), $n^{\circ} 2632$.

(194) $\mid A(A), n^{\circ} 2835$.

(195) $\mid A(C), n^{\circ} 728$.

(196) Me baso en el estudio de Viguera, $\mathrm{M}^{\star} \mathrm{J}$., Aragón musulmán (Zaragoza 1981), pp. 134-44, especialmente p. 143 , donde corrige la cronología de Mundir 11 generalmente aceptada, recogida entre otros por Turk, A., El Reino de Zaragoza en el siglo XI de Cristo ( $V$ de la Hégira) (Madrid 1978), pp. 51-6 y por Wasserstein, op.cit., p. 94.

(197) Abenházam, 1, 100. 
cent...."(198). Ningún comentario sobre la acusación de que al-Talamankī era harāurī.

Más recientemente, Wasserstein ha hecho referencia al caso diciendo (los puntos de interrogación son míos) (199): "In 425/1034 he was accused of heresy. In spite of his very advanced age the was already over eighty at this time) he seems to have been punished for this (?), although, thanks to the intervention of the qādi of Talamanka (?), he avoided a death penalty (?), and he survived for another four years thereafter. The number of his pupils, and the influence which he might exert upon them, may have increased the desirability of prosecuting him".

Mayor interés, rigor y profundidad tiene el estudio de Ibn Hamādr. Por un lado, pone de relieve que el caso del proceso contra al-Talamankī es un excelente ejemplo del valor de los diccionarios biográficos como fuentes, ya que es precisamente una obra del género (la Takmila de lbn alAbbār) la única que ha conservado la información al respecto: ni las crónicas históricas ni las compilaciones jurídicas (como los Ahkām de lbn Sahl o el Mi yār de al-Wansarīsī) mencionan este asunto (200). Pasa revista con bastante detalle a los pormenores del proceso; según él, la mención del cadí Muhammad b. 'Abd Allāh b. Furtūn es un error, ya que se trataría en realidad de Abū "Abd Allāh Muḥammad b. Fūrtiš(201). Debería haber especificado a cuál de los posibles "Muhammad b. Fūrtis" se refiere, ya que hay varios como puede comprobarse consultando el cuadro genealógico de la familia elaborado por Molina y Ávila. Según dicho cuadro, podría tratarse tanto de los $n^{\circ} \mathrm{s} 7$ y 10 (el primero corresponde al mencionado en 1.5., $\left.\mathrm{n}^{\circ} 25\right)$. Aunque la posibilidad de una confusión debe tomarse en consideración, me inclino a pensar que no es tal, ya que parece Iógico suponer que Ibn al-Abbār la habria advertido y hecho por consiguiente algún comentario al respecto. No sólo no lo hace, sino que tiene entradas separadas para cada uno de esos personajes (202). Ibn Hamādi si llama la atención sobre la acusación de harūrí, ya que parece implicar que nuestro personaje habría pertenecido al jāriŷismo, secta ésta que en el $\mathrm{s} . \mathrm{V} / \mathrm{XI}$ apenas si tenia presencia en al-Andalus y ello entre los "nuevos" beréberes como los birzālíes (203). Por otro lado, la formación recibida por al-Talamankī aparece, según lbn Hamādī, como plenamente dentro de los cauces tradicionales (204), tal y como se

(198) Cito en esta ocasión la versión original francesa, pp. 131-2, que corresponde a la (pésima) traducción española, pp. 151 y cf. pp. 126-7.

(199) Ob.cit., pp. 179-80.

(200) Art.cit., p. 8. Sin embargo, no se detiene a analizar las fuentes de Ibn al-Abbãr.

(201) Art.cit., p. 11.

(202) V. IA(C), n's 1058, 1071.

(203) V. al respecto Fierro, Heterodoxia, p. 172, así como Ibn Hazm, Fișal, IV, 144-6, trad. Asín Palacios en Abenházam, V, 72-8.

(204) Señala por ejemplo que al-Talamankĩ es uno de los transmisores más importantes del Muwațta', según se puede comprobar en los fahāris del cadí 'Iyāḍ y de Ibn 'Ațyya. 
deduciría de sus transmisiones y de las obras por él compuestas (cf. en cambio mis consideraciones al final del apartado 1.6.). En su opinión, lo que fue realmente determinante en la postura de al-Talamankī fue su oposición a los așhāb al-bida'/al-ahwă', pues habría contemplado su condena a muerte incluso cuando formaban parte de los sālihì l-muslimina. La acusación de harūrì no debería ser tomada pues como acusación de "jāriŷismo" en el sentido de secta propiamente dicha, sino en su sentido primero, es decir, como una manera de indicar su oposición sin paliativos (tašaddud) a los innovadores. En suma, al-Talamankī no habría sido acusado de ser jāriŷ́ desde un punto de vista doctrinal la saber, en cuanto a su profesión de fe, doctrina jurídica y postura política), sino por su rigor (śidda) similar al de los jāriŷies. De lo que se trata pues es de averiguar contra qué o quienes se dirigía esa oposición y ese rigor de alTalamankī: ¿contra las desviaciones morales?, ¿contra el clima que predominaba durante la época de los reinos de taifas?, ¿contra los alfaquíes mundanos más preocupados por las cosas de este mundo que por la religión, actitud ésta que fue la que determinó la actividad de al-Gazāi cuya vida transcurre medio siglo después de la muerte de al-Talamankĩ? Fuese lo que fuese, al-Talamanki estaba en contra de lo que para él eran innovaciones perniciosas en la sociedad andalusí, pero frente a los demás mālikies, propugnaba que había que combatir esas innovaciones con la espada. En suma, al-Talamankī sería el Abū 'Imrān al-Fāsī (205) de al-Andalus.

2.5. En mi opinión, para entender el proceso contra al-Talamankī hay que reconstruir lo que debió de ser su doctrina sobre el imāmato $(206)$.

El califato omeya fue abolidó por los Banū Ŷahwar en el año $422 / 1031$, tras un periodo en el que se alternaron e incluso coexistieron varios califas. Tras la abolición, los diversos reyes de taifas o bien reconocieron (de forma más teórica que real) al califa 'abbāsí o bien a algún pretendiente omeya, destacando entre ellos el falso Hišām II, proclamado por los 'abbādíes en 414/1023. Ibn Ŷahwar, por su parte, fue elegido šyj al-ŷamā'a (207).

Ibn Hazm reaccionará ante esta situación elaborando su conocido legitimismo omeya (208) y algunos andalusies (sobre todo poetas)

(205) V. sobre este destacado alfaquí māliki de Ifrīqiya Idris, H.R., "Deux maītres de l'école juridique Kairouanaise sous les Zirides", AIEO XIII (1955), pp. 42-60.

(206) Es una lástima que no se haya conservado la obra que Abū I-Walid al-BãŷT compuso sobre ușül al-diyānāt, pues sabemos que en ella trataba la cuestión del imamato: v. A.M.Turki, Polémiques entre lbn Hazm et Bägí sur les principes de la loi musulmane (Argel s.d.), pp. 324-5. Una panorámica de las doctrinas relativas al imamato que estaban en circulación en al-Andalus en época de alTalamankí se puede encontrar en Ibn Hazm, Fiṣal, IV, 72-131, trad. Asín, Ábenházam, V, 7-48.

(207) V. Ibn al-Jațīb, Kitāb a'māl al-a\%ām (ed. E. Lévi-Provençal, $2^{*}$ ed., Beirut 1956), p. 147.

(208) V. Turki, A.M, "L'engagement politique et la théorie du califat d'Ibn Hazm 
parecen haber creído en el derecho de los hammüdíes al califato por su parentesco con el Profeta (209). Pero la mayor parte de los ulemas parece haberse limitado a aceptar la situación existente (ausencia de un califa unánimemente reconocido por la toda la comunidad musulmana) sin pretender cambiarla, al menos hasta que la caída de Toledo en manos cristianas obligó a un replanteamiento.

Al-Talamankī parece haber sido sospechoso de propugnar otra solución. Cuando tiene lugar su proceso (año 425/1034), la dinastía tuỹibí parece que todavía sigue reconociendo al último califa omeya de Córdoba, Hišām III, refugiado en Lérida. Sabemos que las gentes de esa ciudad solicitaron la opinión de al-Talamankī: tal vez fue en algo relativo a la cuestión califal y si recordamos que entre los acusadores de al-Talamankī hay clientes omeyas, podemos también formular la hipótesis de que ello fue porque en su respuesta al-Talamankī no se mostró favorable a la dinastía omeya. A partir de esta hipótesis y de los otros datos de que disponemos, creo que no es aventurado suponer que la solución de nuestro personaje a la cuestión del imāmato era que el imām debe ser el mejor musulmán de la comunidad, liberando así la institución califal de las ataduras de la genealogía (nasab) (210). En este sentido parece que hay que entender la acusación de ser harūri, formulada por sus enemigos con objeto de descalificar una postura que no era únicamente la de la secta jāriŷí: sabemos por ejemplo que el teólogo aš‘arí y alfaquí mālikí alBāqillānī fue acusado de mantener esa postura (211). Hemos visto que la acusación de que propugnaba dar muerte a los "virtuosos" de entre los musulmanes (yarà wad" al-sayf fi sälihï l-muslimina) está en relación con la acusación anterior de jāriŷismo: el rigorismo moral de al-Talamankī, su encendida oposición a la degradación de la época y sus virulentos ataque contra los innovadores le habrian llevado, según sus acusadores, a declarar lícito dar muerte a los musulmanes que él consideraba habían incurrido en rebeldía contra Dios y su religión y que eran en cambio "virtuosos" desde el punto de vista de sus acusadores. Hay un pasaje conservado por Ibn 'I ḋārī que tal vez podría ponerse en relación con este punto: durante el gobierno de 'Abd al-Rahmān Sanchuelo, el cadí lbn Dakwān se mostró reticente frente a quienes propugnaban, con objeto de acabar con el 'āmirí, lanzar el ejército contra la ŷamā'a de Córdoba, pues

(384/994-456/1064)", BEO XXX (1978), pp. 221-51.

(209) V. Makki, M.'A., "al-Tašayyu' fī l-Andalus", RIEEl II (1954), pp. 93-149.

(210) No debió ser el único. Por ejemplo, del cadí lbn García se dice que solía repetir la aleya "El más noble de vosotros a los ojos de Dios es el que es más piadoso": $v$. al respecto Granja, F. de la, "Ibn García, cadi de los califas hammūdies (Nuevos datos para el estudio de la šu'übiyya en al-Andalus) ", Al-Andalus XXX (1965), pp. 63-78, pp. 75-6.

(211) V. Ibn . Hazm, Fisal, IV, 126-9, trad. Asín, Abenházam, V, 21-5; Turki, "L'engagement politique", p. 88. Cf. sin embargo el estudio de Ibish, Y., The political doctrine of al-Baqillani (Beirut 1966) y Abel, A., "Le chapitre sur l'imāmat dans le Tamhīd d'al-Bāqillānī", Le shi'isme imāmite (París 1970), pp. 55-67, donde no aparece semejante idea. 
entre ellos había gentes virtuosas (șālihūun) y que no habian incurrido en pecado (212).

Ese rigorismo moral de al-Talamankī pudo verse influido por doctrinas järiŷíes, aunque en mi opinión debe ser puesto en relación con sus ideas ascético-místicas. Si el pasaje señalado en el apartado 2.3., $\mathrm{n}^{\circ}$ 2 , está bien interpretado, alrededor de al-Talamankī se había formado un grupo de seguidores (ŷmā'a), siendo él su jefe espiritual y llamándosele "el primero de la comunidad" (awwal al-ŷamā'a). El término ŷamā'a parece haber sido utilizado para designar la comunidad musulmana de al-Andalus, como hemos visto en el caso de Ibn Ŷhwar.

El punto de partida de al-Talamankī debió ser un deseo de perfeccionamiento espiritual sin pretensiones al poder político. Pero una vez que se emprende ese camino, el resultado puede ser la rebelión contra el poder constituido: piénsese en el caso de Ibn Barraŷān (213) y en el de Ibn Qasī, discípulo de Ibn al-'Arīf (214). A pesar de que el silencio de las fuentes no ofrece ninguna evidencia al respecto, pienso que los alfaquíes que acusaron a al-Talamankī debieron contar con el apoyo del emir tuŷioí. Si ello fue así, tendríamos un caso ejemplar de un cadí apoyando y exculpando a un ulema que ha empezado a ser visto como peligroso por el poder político, aunque también es cierto que al-Talamankī, tras la declaración de inocencia, abandonó Zaragoza, posiblemente por no tener garantías de que el proceso no pudiese volver a ser incoado.

2.6. Concluyendo, creo que para entender el proceso contra alTalamankỉ hay que tener en cuenta fundamentalmente dos aspectos:

a) la actividad intelectual de al-Talamankī, dirigida a la renovación del Islam peninsular mediante la introducción de nuevas disciplinas y el desarrollo de las ya conocidas, despertó la enemiga de ciertos sectores del mundo de los ulemas incapaces de reconocerse en el Islam que se les proponía. El elemento más perturbador debió residir en sus concepciones misticas: la defensa de los milagros de los santos era vista por ciertos sectores como una amenaza para la figura del profeta Muhammad por lo que suponía de rivalidad para sus poderes especiales, al tiempo que como una innovación en las creencias predominantes hasta el momento, basadas en la absoluta separación entre Dios y el hombre, separación que ahora venían a salvar los santos. La acusación de ser harūrí y de propugnar el combate a muerte y sin piedad contra los innovadores se puede interpretar como un intento de descalificar su rigorismo moral y sus ideales de perfección espiritual.

b) Pero las ideas místicas de al-Talamankī también pudieron llevarle a dar una respuesta a la cuestión del imamato que no era la propuesta en siglos anteriores en el al-Andalus omeya y que bien pudo ser que el imām

(212) al-Bayān al-Mugrib, t. III (ed. E. Lévi-Provençal, París 1930), p. 67.

(213) V. Nwya, "Notes sur quelques fragments inédits de la correspondance d'lbn alArîf avec Ibn Barrajān", Hespéris 1956, pp. 217-21 sobre las pretensiones al imamato de lbn Barraŷān.

(214) V. Dreher, J., "L'imāmat d'lbn Qasi à Mértola (automne 1144-été 1145) Légitimité d'une domination soufie?", MIDEO 18 (1988), pp. 153-210. 
debe ser el mejor musulmán de la comunidad, liberando así a la institución califal de las ataduras de la genealogía. Si ésta fue su doctrina, era tal que bien pudo dar lugar a la acusación de jāriŷismo, doctrina que se caracteriza por resolver de esa manera el problema del imamato. Hemos visto que alrededor de al-Talamankī parece haberse formado un grupo de seguidores a modo de comunidad ( $\left.\hat{y} a m \bar{a}{ }^{\prime} a\right)$, cuya jefatura le era reconocida, recibiendo el nombre de "el primero de la comunidad" (awwal al-ŷamāa). Si el texto en el que me baso está bien interpretado, tendríamos aquí un precedente del camino que seguirán más tarde lbn Barraŷān e Ibn Qasī.

Relación de las siglas correspondientes a las fuentes consultadas.

D = AL-ḌABBT, Bugyat al-multamis, ed. F. Codera y J. Ribera, Madrid 1884-5 (BAH III)

$\mathrm{DM}=\mathrm{IBN} F A R H U \mathrm{UN}$, al-Dibāŷ al-mudhab, 2 vols., EI Cairo 1972

DT = AL-MARRĀKUŠT, al-Dayl wa-l-takmila, vol. I, ed. M. Ibn Sarîfa, Beirut s.d.; IV, ed. I. 'Abbās, Beirut s.d.

$\mathrm{H}=\mathrm{AL}$-HUMAYDİ, Yadwat al-muqtabis, ed. M. Ibn Tāwīt, El Cairo $1372 \dot{H}$.

Huṣn = AL-SUYŪTī, Huṣn al-muhāạara fī ajbār Miṣr wa-l-Qāhira, 2 vols. El cairo 1967-8

IA $=$ IBN AL-ABBĀR, al-Takmila li-kitāb al-Șila, ed. F. Codera, Madrid 1887-9 (BAH V-VI)

$\mid \mathrm{A}(\mathrm{A})=\mathrm{IBN}$ AL-ABBĀR, al-Takmila li-kitāb al-Ṣila, ed. M. Alarcón, Madrid 1915

$\mathrm{IA}(\mathrm{C})=$ IBN AL-ABBĀR, al-Takmila li-kitāb al-Ṣila, ed. 'I. al-Ḥusaynī, EI Cairo 1955

IB = IBN BAŠKUWWĀL, Kitāb al-șila, ed. F. Codera, Madrid 1882-3 (BAH |-II)

$\mid \mathrm{B}(\mathrm{C})=$ IBN BASKUWWĀL, Kitāb al-șila, ed. 'I. al-'Atțār, El Cairo 1955

'lbar = AL-DAHABI, al-'lbar fi jabar man gabar, 5 vols., Kuwait 1960

IF $=$ IBN AL-FARADİ, Ta'rij 'ulamā' al-Andalus, ed. F. Codera, Madrid 1891-2 (BAH VIII)

IJ = IBN JAYR, Fahrasa, ed. F. Codera y J. Ribera, Zaragoza 1893 $(B A H \mid \mathrm{X}-\mathrm{X})$

IZ = IBN AL-ZUBAYR, Șilat al-șila, ed. E. Lévi-Provençal, Rabat 1937

Lisān = IBN HAŶYAR, Lisān al-mīzān, 5 vols., Beirut 1971

Mīzān = AL-DAHABī, Mīzān al-ítidāl, 4 vols., Beirut s.a.

NT = AL-M̄MAQARTi, Nafh al-tīb, ed. I. 'Abbās, 8 vols., Beirut 1968

Sadarāt = IBN AL-'IMĀD, Sạdarāit al-dahab fi ajbār man dahab, 4 vols., Beirut s.a.

SD = AL-DAHAB̄̄, Siyar a'/ām al-nuba/ā', varios editores, 23 vols., Beirut 1985

$\mathrm{TH}=$ AL-DQAHABĪ, Tadkirat al-huffāz, 4 vols., Hyderabad 1968-70

TM = "IY $\overline{A D}$, Tartīb al-madārik", varios editores, 8 vols., Rabat s.d.1983

WS = AL-ṢAFADĪ, al-Wāfī bi-l-wafayāt, varios editores, 22 vols., Wiesbaden 1962-83. 